\title{
Afterlives of Komitas K'eōmurchean (I656-I707): Commemorating an Istanbul-Armenian Martyr in Armeno-Turkish Literature and Sacred Pilgrimage
}

\author{
Henry R. Shapiro*
}

\begin{abstract}
Komitas Kömürciyan’n Ölümünden Sonrası (1656-1707): Şehit Bir İstanbul Ermenisinin Anısını Ermeni Harfli Türkçe Edebiyatı ve Kutsal Hac Bağlamlarında Düşünmek

Öz - Komitas Kömürciyan (1656-1707) İstanbullu Ermeni bir papaz ve aynı zamanda üretkenliği ile tanınan yazar Eremya Kömürciyan'ın küçük kardeşidir. Bir Apostolik Ermeni olan Eremya rahip değildi. Komitas ise Katolik öğretilere sahip çıkan ve tam da bu öğretiler hasebiyle Apostolik Kilise üyeleri ile çatışma yaşayan bir papazdı. En nihayetinde Osmanlı Kadı Mahkemesi tarafından ölüme mahkum edilerek idam edildi. İlginçtir ki ölümünden sonra mezarı her kesimden Ermeni'nin, hatta bazı Rum ve Müslümanların da hürmet gösterdiği ekümenik bir alana dönüştü. Bu makale, öncelikle ölümünden sonra Komitas'ın Ermeni-harfli Türkçe edebiyatında (Ermeni alfabesi ile Türkçe yazılmış) nasıl konumlandığını betimlemektedir. Sonrasında Komitas'ın yargılanma sürecinin ve Ermenice yazılmış mezar taşının Osmanlı mahkeme kayıtlarındaki transkripsiyon ve çevirilerini ortaya koymaktadır. $\mathrm{Bu}$ bakımından bu makale erken modern dönemdeki Ermeni Katolik tarihine bir 1şı tutmakta, Komitas'ın hayatını ve ölümünden sonrasını Osmanlı kültürel tarihindeki akımlar ekseninde irdeleyerek "neo-şehitlik" ve kutsal hac pratikleri bağlamlarında kavramsallaştırmaktadır.

Anahtar kelimeler: Komitas Kömürciyan, Eremya Kömürciyan, Ermeni-harfli Türkçe, Neo-Şehitlik, Ermeni Katolikleri, Ekümenik Kutsal Alanlar, Mezhepleşme.
\end{abstract}

* The Van Leer Jerusalem Institute.

I am grateful to Aslı Niyazioğlu, Erin Pinon, Cesare Santus, Michael Stone, and the anonymous reviewers at the Journal of Ottoman Studies for reading this piece and offering kind suggestions. I also thank Sebouh Aslanian for very generously sharing some photos from his research in the archives of the Propaganda Fide in Rome and the British Library in London. 
With a mournful countenance, I lament [the state of] my people, And grieving in the heart, I cry and weep,

I recall the nobility of my people,

My heart being unable to bear it, I cry and weep,

I weep, I weep, I cry and weep.

Now, where are our princes, where do they appear?

Where are their dominions, which do not appear?

Because they abandoned us orphaned and tearful,

For that [reason] I lament, I cry, and I weep copiously. ${ }^{1}$

These verses of lamentation were written by an Armenian priest, living in hiding in his hometown of Istanbul at the beginning of the eighteenth century. The verses refer in general terms to the sad state of "my people," namely the Armenians of the Ottoman Empire. But the actual circumstances of this priest's dangerous predicament were only partially related to Ottoman governance, and had much more to do with religious tensions within the Ottoman-Armenian community. Those tensions would ultimately lead to his execution at the direct instigation of the Armenian Patriarchate of Constantinople. The priest's name was Komitas K'eōmurchean.

The K'eōmurchean (usually transcribed "Kömürciyan" by Turkologists) family was one of great intellectual and ecclesiastical distinction in seventeenth and eighteenth-century Istanbul. The lineage's most famous scions were two brothers, Eremia (1637-1695) and Komitas (1656-1707). Eremia was Istanbul's first great home-born Armenian author and intellectual, a polymath of extensive learning and voluminous literary productivity. Like the majority of Armenians living in

1 Step'anos Avk'ereants', Allah'ın aziz kulu Kömürceants Der Gomidas kahanaynın varkı ve Nahadagutünü, (Trieste: Self-published with persmission of Mikhit'arean publishing house, 1798), p. 22. I have prepared a complete translation of this booklet which is forthcoming in Ottoman Communities in the Age of Confessional Polarization: A Sourcebook, ed. T. Krstic et al., (Piscataway: Gorgias Press). The book was written in Armeno-Turkish, but as was very common in early modern Armeno-Turkish works, there are portions in Armenian,

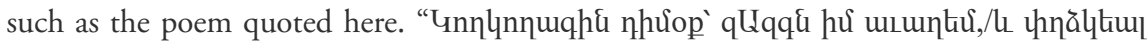

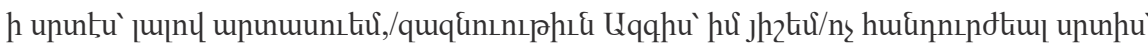

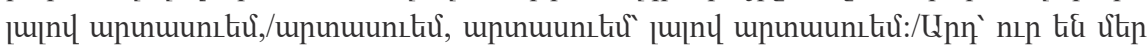

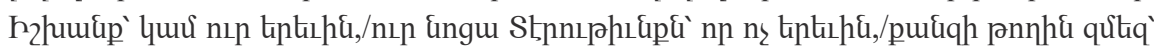

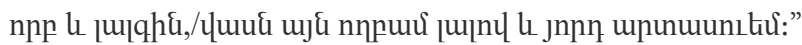


the Ottoman Empire, he was an Apostolic Armenian layman, one with close ties to the prominent churchmen of his day. Komitas, in contrast, was a priest who became an officially beatified martyr of the Roman Catholic Church. ${ }^{2}$

This article draws on sources in Ottoman Turkish, Armenian, and ArmenoTurkish (Turkish written in the Armenian alphabet) ${ }^{3}$ to document Komitas' trial and commemoration in Ottoman Istanbul, showing how Komitas was remembered and celebrated long after his death primarily among Armenian Catholics, but also by Apostolic Armenians, Protestant Armenians, and even some Greeks and Muslims. By doing so, it will provide a window into the early modern history of Armenian Catholics in the Ottoman Empire. Komitas was distinguished by his lineage and long-enduring veneration, but he is representative of a broader movement against Catholic activities organized by the Apostolic Armenian Patriarchate of Constantinople in cooperation with the Ottoman state. ${ }^{4}$

2 Short biographies of both Eremia and Komitas can be found in Azgapatum [National History] (originally published between 1913 and 1927), the master opus of Malak ia Ōrmanean. Ōrmanean served as the Apostolic Armenian Patriarch of Constantinople from 1896 until 1908, though he had been a Catholic in his youth. See Malak'ia Ōrmanean, Azgapatum II (Beruit: Sewan, 1960) on pages 2666-2667 and 2756-2759, respectively. An additional biographical account of Eremia is available in English in Andreas Tietze and Avedis K. Sanjian, Eremya Chelebi Kömürjian's Armeno-Turkish Poem: The Jewish Bride (Wiesbaden: Harrassowitz, 1981), pp. 12-21; while a more detailed French narrative of Komitas' life and martyrdom is available in $\mathrm{H}$. Riondel, Une page tragique de l'histoire religieuse du Levant (Paris: Gabriel Beauchesne, 1929).

3 All primary source translations from Armenian, Ottoman Turkish, and Armeno-Turkish in this article are my own. For all Armenian transcriptions, I made use of the Classical Armenian transcription alphabet found at the beginning of Robert W. Thomson, Moses Khorenats ' $i$ : History of the Armenians (Cambridge: Harvard University Press, 1978). For all transcriptions of Armeno-Turkish texts I use the transcription alphabet printed at the beginning of the Turkish version of Kevork Bardakjian, Reference Guide to Modern Armenian Literature (Istanbul: Aras, 2013). For the sake of consistency in the English text and translations, I always translate Komitas' name according to the Classical Armenian transcription system - even in translations of Armeno-Turkish—while transcribing it as "Gomidas" in the Armeno-Turkish primary-source footnotes. Besides from the name Komitas, there will be some discrepancies between transcriptions of names in translations of Armeno-Turkish with transcriptions from Armenian arising from the need to use different transcription alphabets.

4 The broader history of this conflict will be the topic of an anticipated dissertation currently being written by Daniel Ohanian of the History Department at UCLA, entitled, "Church 
We know from the writings of early modern authors-including both Christians, like Eremia himself, and Muslims, such as the famous traveler Evliya Çelebi (1611-1682) — that anyone making a jaunt through Istanbul or any major Ottoman city was bound to encounter the tombs of saints, constant reminders of holy lore and sites of sacrality. When imagining the sacred landscape of Ottoman Istanbul, historians would not fail to recall Muslim türbes, such as the famed türbe of Eyüp Sultan, a companion of the Prophet Muhammad whose grave was supposedly rediscovered in the fifteenth century, during the reign of Mehmed II (1432-1481). Here we focus on an Armenian Catholic martyr's trial and commemoration, documenting how Komitas' life and execution was remembered in Armeno-Turkish literature and how his tombstone became a site on the multireligious sacred landscape of Istanbul.

\section{Martyrdom and Saints' Tombs in the Writings of Eremia}

Ironically, some of the best sources for unearthing precedents of Komitas' martyrdom and commemoration were written by his very own brother, Eremia. The oldest of Eremia's many works is a personal diary ${ }^{5}$ that he began keeping in 1649 at the age of twelve. ${ }^{6}$ The diary includes several narratives about so-called "neo-martyrs," Christians who were executed by the Ottoman state either because they were apostates from Islam, or because they had converted to Islam and then reverted back to Christianity. ${ }^{7}$

An example of one such account begins in Eremia's diary entry for June 26, 1655. There Eremia describes how an Armenian named Rěstagēs was in the market one day and made the mistake of affronting the Islamic religion. He was

of Armenia, Church of Rome: Faith, Print, and Power in Ottoman-Armenian History, 1688-1717."

5 Eremia K'eōmurchean, Oragrut'yun Eremia Ch'èlēpi K'èomyurcheani, ed. Mesrop Nshanean (Jerusalem: Tparan Srbots' Yakobeants', 1939).

6 The journal's earliest entry-for 1648 - has been shown to be a later interjection. See Gayane Ayvazyan, “Eremia Ch'lepi K'yomurchyani ‘Ōragrut'yun’ Erki Mi Anhayt Skzbnalbyuri Masin,” Hayagitut'yan Harts'er, 1/7 (2016): 51-60.

7 The most famed compiler of such stories in Greek is Nikodēmos o Agioreitēs whose work has been translated into English. See Nikodmos o Agioreits, Neon Marturologion ètoi Marturia tōn Neofanōn Martu (Athens: F. Karampini and K. Vafa, 1856); and Nomikos Michael Vaporis, Witnesses for Christ: Orthodox Christian Neomartyrs of the Ottoman Period, 1437-1860 (Yonkers: St. Vladimir’s Seminary Press, 2000). 
seized and given the choice between renouncing Christianity and becoming Muslim or being killed. After a convoluted series of events, he ultimately converts to Islam unwillingly but later reverts to Christianity and renounces Islam at a public trial. As a result, he gets executed by the state. ${ }^{8}$ In his story, we see the standard pattern of a "neo-martyr"'s tale: willing or unwilling conversion of a Christian to Islam, apostasy in which the Christian returns to his old faith, a trial in which the apostate is given the chance to revert to the religion of the state, and execution if he refuses. ${ }^{9}$ Many more examples written by other Armenian authors can be found in compilations of such tales. ${ }^{10}$

Eremia's interest in the religious history of Istanbul went beyond the accounts of "neo-martyrs" one encounters in his diary; in other works he also recorded the histories of sacred graves and sites of visitation. Eremia wrote a poetic tour of Istanbul which includes the lives of saints and descriptions of their tombs, places which would become sites of commemoration and remembrance. For example, Eremia sarcastically describes a famous seventeenth-century Ottoman holy fool named Elekci Dede (Papa Sieve) whose tomb was located near the Silivri Gate. Eremia writes,

The twenty-fifth [gate] is Silivri, inside is a cami (mosque), and opposite is a bathhouse.

Nearby the gate, outside of it,

is a mezar (grave) of Elekci Dede (Papa Sieve).

He never spoke,

but he was always eating [the fabric] of sieves.

He would wander behind the Armenian gypsies,

who would pity him and have him eat sieve.

His whole body was covered in black, and he was entirely arab (black-skinned) up to the head.

Summer and winter, he was [always] naked,

8 K'eōmurchean, Oragrut'yun, pp. 77-79.

9 Rĕstagēs' story and the broader theme of neo-martyrs in Eremia's corpus is discussed in greater detail in Polina Ivanova, "Armenians in Urban Order and Disorder of SeventeenthCentury Istanbul," Journal of the Ottoman and Turkish Studies Association, 4/2 (2017): 256258.

10 See Hakob Manandyan and Hrach'ya Acharyan, Hayots ' Nor Vkanerě: 1155-1843 (Ejmiatsin: Tparan Mayr At'oroỷ S. Ējmiatsin, 1903). 
he was standing upright, neglected.

With one hand he would eat the sieve,

and the other hand was on [his] mefred baba (big penis)

He didn't have hair or a beard,

he was brutish and mute like a hayvan (animal).

When he died they called him a veli (friend of God, saint), and they hastened to his funeral. ${ }^{11}$

Later Eremia adds,

They made a mezar (tomb) and a shelter [for him], and they hung a sieve on it as a sign.

Until today guards sit there, they preach saying that it is a place of healing.

Women, khatun (ladies), and khanım (girls), and sultans hastened there in carriages.

Others too read fatihes [the first chapter of the Koran], imploring for şifa (healing) from him.

Jugs on the mezar (tomb), were placed ready full of water,

As a remedy for those yearning for children, to give a boy to women who wanted to get pregnant, or who were barren.

They used to rub this water on their eyes, faces, chests and pisdan (breasts)... ${ }^{12}$

11 Eremia K'eōmurchean, Eremia Ch'ēlēpi K'ēōmyurchean Stampoloy Patmut'yun, ed. Vahram Y. T'orgomean (Vienna: Mkhit'arean Tparan, 1913), pp. 46-47. "Puuu til hhiqu

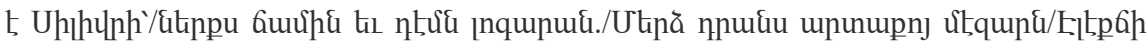

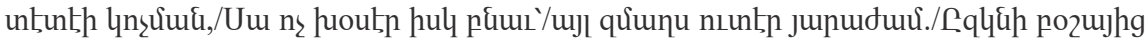

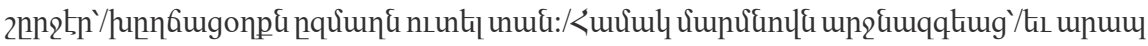

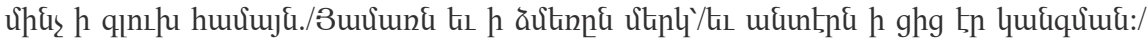

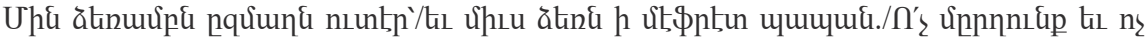

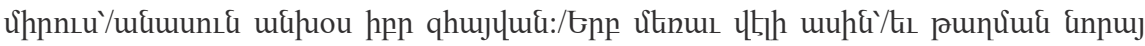
цnıрuiguú."

12 K'eōmurchean, Eremia Ch'èlēpi K'ēōmyurchean Stampoloy Patmut'yun, pp. 48-49. "Uţqup

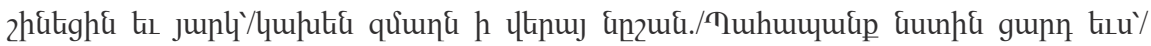

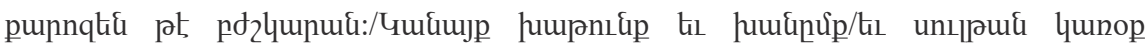

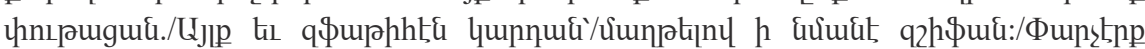


Eremia was not the only seventeenth-century author to commemorate Elekci Dede, and his odd story is also recounted in the travelogue of Eremia's contemporary, Evliya Çelebi. ${ }^{13}$ Saints' tombs were part of the physical and spiritual landscape of both Muslims and Christians in the Ottoman Period. Sometimes they shared each others' holy sites. ${ }^{14}$

Thus, the topics of Christian martyrdom at the hands of Ottoman authorities and of the formation of holy sites at saints' graves are both themes addressed in the writings of Eremia. Eremia died in 1695, more than a decade before his brother's execution. In all probability, he never would have guessed that his little brother would bring together these two themes with-from the perspective of Apostolic Armenians like Eremia-a scandalous twist, namely, Komitas' Catholic leanings. Since the history of Catholics in the early modern Ottoman Empire-as opposed to the Late Ottoman Empire-remains relatively neglected in scholarship, it would be worthwhile to provide a short history of early Catholic missionary activity in Istanbul and Anatolia.

\section{Armenian Catholics in the Early Modern Ottoman Empire}

The history of Armenian Catholics goes back much farther than the Ottoman period. Many Armenians embraced Catholicism during the Crusader Period in Cilicia in the late eleventh and early twelfth centuries. Later in the fourteenth

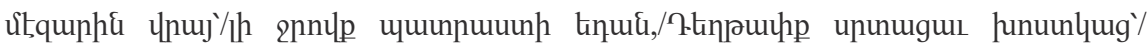

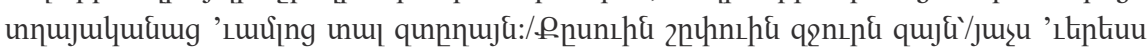

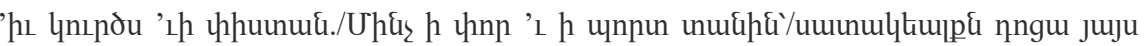
£々ưuq:" My translation of selections of Eremia's History of Istanbul-including the passage in this footnote and the previous one-is forthcoming in The Ottoman World: A Cultural History Reader, 1400-1700, ed. Hakan T. Karateke and Helga Anetshofer (Berkely: University of California Press).

13 Evliyâ Çelebi Seyahatnâmesi, vol. I, ed. Seyit Ali Kahraman, Yücel Dağlı, Robert Dankoff (İstanbul: Yapı Kredi Yayınları, 2011), p. 189.

14 For many examples of holy sites shared by Muslims and Christians in medieval and Ottoman Anatolia, see F.W. Hasluck, Christianity and Islam under the Sultans, vol. I-II (Oxford: Oxford University Press, 1929); Heath W. Lowry, In the Footsteps of the Ottomans: A Search for Sacred Spaces \& Architectural Monuments in Northern Greece (Istanbul: Bahçesehir University Publications, 2009); and Dionigi Albera and Maria Couroucli (eds.), Sharing Sacred Spaces in the Mediterranean: Christians, Muslims, and Jews at Shrines and Sanctuaries (Bloomington: Indiana University Press, 2012). 
century Catholic missionaries were active in Anatolia and Nakhchivan, catalyzing a rich "Armeno-Latin intellectual exchange." 15

By the early modern period, however, most traces of an Armenian Catholic presence in Anatolia seems to have disappeared. Likewise, in sixteenth-century Istanbul Catholic life was primarily limited to European merchants, slaves, and prisoners. ${ }^{16}$ But Jesuits and Capuchins began to arrive in the Ottoman capital in the late sixteenth century in the aftermath of the Council of Trent, ${ }^{17}$ and they laid the groundwork for the next stage of Apostolic-Catholic competition in Anatolia and Istanbul.

Two authors who document Catholic missionary activity among Armenians in seventeenth-century Istanbul are the chronicler Grigor Daranalts'i (15761643), and perhaps unsurprisingly, Eremia K'eōmurchean. Grigor was an Armenian bishop based in Rodosto (Tekirdağ) and author of a lengthy chronicle which extensively describes events in Ottoman and Armenian history of the first half of the seventeenth century. ${ }^{18}$ Grigor was an Apostolic Armenian, and already in his chronicle it is possible to see deep anxiety about the growing influence of Catholic missionaries among Ottoman Armenians. Apostolic Armenians' concerns about Catholic influence were exacerbated by the creation of a Uniate Armenian bishopric in Lvov, Poland in 1630, the topic with which Grigor concludes his chronicle. ${ }^{19}$ Eremia also documents the spreading popularity of Catholicism among the Armenians of Istanbul in his diary. For example, in his diary entries for May 24 and 25, 1656, he describes how Armenians priests were lamenting the "scandal" that men were turning to the faith of the "Franks,"20 i.e., Catholicism. These early signs of Catholicism's increasing popularity among Istanbul Armenians were results of institutional efforts in Rome. In 1622 the Sacred Congregation for the Propagation of the Faith (De Propaganda

15 Sergio La Porta, "Armeno-Latin Intellectual Exchange in the Fourteenth Century: Scholarly Traditions in Conversation and Competition," Medieval Encounters, 21 (2015): 269-294.

16 Charles A. Frazee, Catholics and Sultans: The Church and the Ottoman Empire: 1453-1923, (London: Cambridge University Press, 1983), p. 72.

17 Frazee, Catholics and Sultans, pp. 73-74.

18 Grigor Daranalts'i, Zhamanakagrut'iwn GrigorVardapeti Kamakhets'wots'kam Daranlts'wots', ed. Mesrop Nshanean, (Jerusalem: Tparan Arak' At'orots' S. Yakobeants', 1915).

19 See Daranalts'i, p. 588.

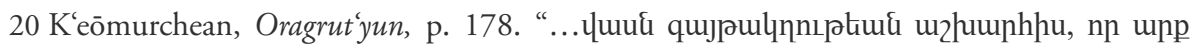

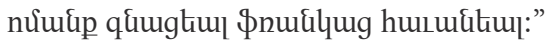


Fide) came into being, which soon went on to establish in 1627 the Collegio Urbano for training missionaries. ${ }^{21}$

A major development in the history of Armenian Catholicism in the Ottoman Empire came with the distinguished career of the famed Abbot Mkhit'ar Sebastats'i (1676-1749). ${ }^{22}$ Mkhitar is a critical figure in Armenian cultural and religious history because he founded an Armenian-Catholic religious order based in Venice which simultaneously sought to preserve and develop Armenian cultural and intellectual life while also synthesizing it with that of the Church in Rome. A large part of his dual mission lay in training missionaries for work in the Ottoman Empire and publishing books that would help missionaries and develop Armenian intellectual life. Mkhit'ar died in 1749, and his successor as leader of the order lacked the authority his mentor had possessed. As Sebouh Aslanian describes in an article entitled "The 'Great Schism' of 1773: Venice and the Founding of the Armenian Community of Trieste," a faction of the Mkhit'areans split off from Venice in 1773 and established a new monastery in Trieste (and later Vienna as well). Like the order in Venice, the one in Trieste would also engage in book-publishing, including many books written in Turkish with the Armenian alphabet (Armeno-Turkish). This was logical both from a financial and an evangelical point of view, as it was printed works in Armeno-Turkish which had the greatest chance of reaching the broadest audience in the Ottoman Empire, where many Armenians were Turkophone. ${ }^{23}$ When writing for erudite churchmen, Classical Armenian, would be the language of choice, but Armeno-Turkish was the most suitable language for addressing the broadest possible Armenian reading public in the Ottoman Empire. ${ }^{24}$

21 Sebouh D. Aslanian, “The 'Great Schism' of 1773: Venice and the Founding of the Armenian Community of Trieste," in Reflections on Armenian Identity in History and Historiography, ed. H. Berberian and J. Daryaee (Irvine: Jordan Center for Persian Studies, 2018), p. 89.

22 For an English biography of Mkhit'ar, see Minas Nurikhan, The Life and Times of the Servant of God, Abbot Mechitar, Founder of the Mechitarist Fathers (Venice: St. Lazarus' Island Press, 1915). For an Armenian account, see Hovhannēs T'orosean, Vark' Mkbit’aray abbayi Sebastioy (Venice: S. Lazar, 1901).

23 Aslanian, “The 'Great Schism' of 1773,” p. 115.

24 For an excellent introduction to the history of Armeno-Turkish literature in the Ottoman Empire, see Sebouh David Aslanian, "'Prepared in the Language of the Hagarites': Abbot Mkhitar's 1727 Armeno-Turkish Grammar of Modern Western Armenian,” Journal of the Society for Armenian Studies, 25 (2016): 78-79. 
Armenian Catholics were not recognized by the Ottoman state as being a separate religious community from the Apostolic Armenians until 1830, ${ }^{25}$ and it seems that the line between Apostolic and Catholic Armenians in the Ottoman Empire probably remained ambiguous until then. On September 26, 1757 an Armenian Catholic student of Mkhitar's named Gevorg of Antep sent a letter from Rome to Ankara which shows that Catholic policies regarding cross-confessional worship were still contested in the eighteenth century. In the letter-which was written in Armeno-Turkish-the Catholic priest Gevorg apologizes to the Armenian Catholics of Ankara for giving them bad advice and corrects his instructions after being reprimanded in Rome. He writes,

When I was among you, I was teaching, and I delivered a writing to you saying that it is permissible to go to the churches of the Armenian heretics [Apostolic Armenians]. With this word, I gave you permission for many things. So many [things] appeared in that book which I gave to you, thinking that they will say these things are not in contradiction to the purpose and canons (sicil) of the holy Roman church. But then I came to Rome and saw with my own eyes how many canons clearly forbade going to the churches of the heretics, being in the presence of their readings ([as a measure] against the trap/danger of being ruined and scandal), becoming a partaker in their liturgies which they say are tainted with the heretic falsehood, and finally joining [with them], which means separation from the true church and [being] in one body with the heretics. Upon reflection, by my own consenting will, being a child of the holy Roman Church, I take back from the book I wrote all the words and instructions which are contrary to the teachings of the holy Roman church. ${ }^{26}$

25 Kemal Beydilli, II. Mahmud Devrinde Katolik Ermeni Cemâati ve Kilisesinin Tanınması (1830) (Harvard: Department of Near Eastern Languages and Civilizations, Harvard University, 1995).

26 Mkhit'arean Monastery Library of Vienna, MS 1514, 1b-2a. “...haçan ki sizde idim oğredir idim ve yazı ile teslim eder idim size ki gitmek cayiz dir deyi hayots hertzuadzoglarının kiliselerine ve bu soz ile çok şeylere izin vermiş idim size nice görunur ol kitabda ki anı teslim etdim size zann etmek ile ki bu şeyler karşı değil dirler niyetine ve sicillerine hromeagan surp yegegetsinin deyi. İlla haçan ki geldim hromaya ve gördum gendi gözlerim ile ol kadar sicilleri ki eşgyarece yasak ederler gitmeği hertzuadzogların kiliselerine ve onların okmumalarının huzurında bulunmağı yıkgınlık duzağı içun kaytaggutün içun ve hessedeş olmak içun o ararogutünlara ki lekelenmiş dirler hertzuadzogluk yanglışlığı ile ve encaminde ilhaklık içun ki olur ç̧marid yegegetsiden ayrılmış hertzuadzogların bir bedeni ile ben gendim düşunmek ile kayet ırzalı radetim ile ol evladı olmak üzre hromeagan surp yegegetsinin geri alırım şu benim yazdığım kitabımdan bir bir cümle o sozu ve talimi ki onlar zıt 
In short, while the priest had initially advised that mixing with Apostolic Armenians could be permitted, he is ultimately forced to retract this advice. ${ }^{27}$ Even after a century and a half of Catholic missionary activities among Ottoman Armenians and the gradual development of a rule against sacramental intercommunion, it was difficult to keep Catholic Armenians away from Apostolic churches, in large part because there were no official Catholic churches. ${ }^{28}$ Though written long after Komitas' trial, this letter documents confessional ambiguity which began in the early seventeenth century, remained the situation in the early eighteenth century during Komitas' period of struggles, and continued until the nineteenth. Sometimes Armenian merchants shifted back and forth between confessions, professing Catholicism in Europe while reverting to Apostolic Armenian Christianity in the Middle East for purely pragmatic reasons, thus making it all the more difficult to distinguish between Catholic and Apostolic Armenians in the early modern period. ${ }^{29}$

In sum, post-Tridentine Catholic missionary activities catalyzed confessional competition among Ottoman Armenians starting at the beginning of the seventeenth century. Yet the boundary between Apostolic and Catholic Armenians was not always clear, nor were the expected modes of relations between Catholic converts and the much larger Apostolic Armenian communities from which they hailed, as shown by extensive debates over the permissibility of attending Apostolic church services. Komitas K'eōmurchean lived on the fault-line of this intra-communal tension, and he ultimately lost his life when the tinderbox of confessional conflict exploded.

dırlar talimine hromeagan surp yegegetsinin.” I have prepared a complete translation of this letter which is forthcoming in Ottoman Communities in the Age of Confessional Polarization: A Sourcebook, ed. T. Krstic et al., (Piscataway: Gorgias Press). An Italian version of the letter exists in the archives of the Propaganda Fide in Rome: ACDF, SO, St. St., M 3-b, f. 900r.

27 For further discussion of Gevorg of Antep, see Cesare Santus, Trasgressioni necessarie. Communicatio in sacris, coesistenza e conflitti tra le comunità cristiane orientali (Levante e Impero ottomano, XVII-XVIII secolo) (Rome: École française de Rome, 2019), p. 421.

28 Cesare Santus describes the broader history of such debates about sacramental intercommunion in Trasgressioni necessarie; and "Conflicting Views: Catholic Missionaries in Ottoman Cities between Accommodation and Latinization," in Catholic Missionaries in Early Modern Asia: Patterns of Localization, ed. Nadine Amsler et al. (London: Routledge, 2019), pp. 96-109.

29 See Sebouh David Aslanian, From the Indian Ocean to the Mediterranean: The Global Trade Networks of Armenian Merchants from New Julfa (Berkeley: University of California Press, 2011), pp. 61-63. 


\section{Komitas Before the Kadı Court}

Recent research by Cesare Santus offers the best historical contextualization of the events leading to Komitas' execution, and of Roman Catholic Church debates about his later beatification. In his article, "The Şeybülislam, the Patriarch, and the Ambassador: A Case of Entangled Confessionalization (1692-1703)," Santus notes the importance of the Venetian conquest of the Island of Chios in 1694 in pushing the Ottoman state to initiate policies aimed at curbing Roman Catholic missionary activity in the empire, as Catholicism became associated with a military enemy. ${ }^{30}$ In his article, Santus describes how an alliance formed between the Ottoman Şeyhülislam Feyzullah Efendi and the Apostolic Armenian Patriarch Awetik' of Tokat, old acquaintances who collaborated in repressing Catholicism. Though Feyzullah was executed during the "Edirne Event" of 1703 and Awetik lost his patriarchal throne soon thereafter, ending up in a French prison, ${ }^{31}$ collaboration between the Ottoman state and the Armenian Patriarchate aimed at preventing the spread of Catholicism among Ottoman Armenians continued after their tenures in power.

Unlike his brother Eremia, who, despite his intimate relationship with the Patriarchate, remained a layman, Komitas became a priest at the St. Gēorg Armenian Church in Samatia, Istanbul. ${ }^{32}$ As will be seen below, he endured years of trouble during periods of anti-Catholic persecution. Finally, during the patriarchate of Hovhannēs of Izmir, he was brought before an Ottoman court, and the Armenian Patriarchate of Constantinople ultimately succeeded in convincing the Ottoman state to have him executed. This author found the original of the Ottoman Turkish court record of his trial (sicil) for the first time in a notebook of records for Galata. Its photograph and translation are appended to this article in Appendix I, while key parts of the text are worthy of careful analysis here.

30 Cesare Santus, "The Şeyhülislam, the Patriarch, and the Ambassador: A Case of Entangled Confessionalization (1692-1703)," pp. 5-6; forthcoming in a volume edited by Tijana Kristic based on proceedings of conference entitled "Entangled Confessionalizations? Dialogic Perspectives on Community and Confession-Building Initiatives in the Ottoman Empire, 15th-18th Centuries" which took place at the Central European University in Budapest, Hungary in June 2018.

31 Santus, "The Şeybülislam, the Patriarch, and the Ambassador," p. 19.

32 Ōrmanean, Azgapatum II, pp. 2756-2757. 
The record of Komitas' trial begins with the following testimony:

In the city of Istanbul and its environs, the priest named Ovannes son of Krikor, who is the Armenian patriarch, made a case in the sharia court—which must be held in reverence-before [these] named Armenians: from the priests of the the Sulu Manastır Church in the above-mentioned city the priest Komitas son of Martiros, the clock-maker Krikor son of Agia, the goldsmith Benli Ariton son of Hachatur, and the liver-salesman Ustosdor son of Krikor. He said, "I demand that the above-mentioned priest Komitas, Krikor, and Ariton be asked and a deposition drafted from the above-mentioned [concerning] whether they have left the Armenian rite and entered the Frankish religion and performed the Frankish liturgy and led many astray and been a cause for leading the Armenian millet astray, and if the above-mentioned liver salesman Ustosdor has left the Armenian religion and met with Armenians who have become Franks, and if he was not coming to church and has also become a Frank."33

According to this passage, Komitas stands accused not only of having become a Catholic himself, but also of having become a Catholic evangelist and of "[leading] many astray," i.e., converting Apostolic Armenians to Roman Catholicisim. Komitas and his associates deny all the accusations, including the claim that they had "entered the Frankish religion," but the Armenian patriarch Hovhannēs (Ovannes son of Krikor in the document) was able to procure numerous witnesses_including several priests—who spoke against them. They testified that

In fact the above mentioned Komitas and Krikor and Ariton have left the Armenian rite, entered the religion of the Franks, and performed the Frankish liturgy. They have led many from the Armenian millet astray, and they have been a cause of sedition. And the above-mentioned liver salesman Ustosdor also doesn't come to church, and he consorts and converses with those who [have left] the Armenian religion and become Franks. On this topic in this way we are witnesses and give testimony. ${ }^{34}$

As is the custom in Ottoman Turkish sicils, no mention is made of the judge's decision or of the punishment to be meted out. One will note the emphasis on the Catholics' association with "the Franks," association which had treasonous implications.

33 Galata Şer'iyye Sicilleri (GŞS) 202, 44b-45a.

34 Galata Şer'iyye Sicilleri (GŞS) 202, 45a. 
Documentation about Komitas' trial became important later in the eighteenth century, when the Roman Catholic Church began conducting research on Komitas for the purpose of his beatification. ${ }^{35}$ Both Cesare Santus and the Sebouh David Aslanian have found documents about Komitas' genealogy and trial in the archives of the Propaganda Fide in Rome. A copy of the sicil from Komitas trial was particularly important for the Catholic Church's efforts to prove that Komitas was executed because of Catholicism. A reproduction of the sicil still exists in the archives of the Propaganda Fide in Rome along with a literal Italian translation made in 1771 during Komitas' beatification trial. ${ }^{36}$

In the course of the eighteenth century, Armenian authors wrote several martyrologies about Komitas' life and death, both in manuscripts and published pamphlets and books. ${ }^{37}$ Some of these would be aimed at an audience back in the Ottoman Empire, namely Armenian Catholics and Apostolic Armenians that the Catholics hoped to convert. As mentioned, when seeking to write for a broad audience of Ottoman Armenians, refined Classical Armenian-the language of the Armenian Church and clergy — was not considered to be the most practical option. Rather communications aimed at "the masses" tended to be composed in the hybrid language of Armeno-Turkish, as most Ottoman Armenians were either Turkophone or bilinguals, knowing a spoken Armenian dialect (not literary Classical Armenian) along with Turkish. Let us now turn our attention to an account of Komitas' life and death composed in Armeno-Turkish for dissemination in the Ottoman Empire, especially the capital Istanbul, which was home to the largest Armenian reading-audience in the world. It was likely this ArmenoTurkish martyrology that was read by the largest segment of pious laypeople, as opposed to priests trained in Classical Armenian.

35 See Cesare Santus, "Un Beato Martire Per La Nazione Martire. La Causa di Beatificazione del Sacerdote Armeno Gomidas Keumurgian (1709-1929)," in Un mestiere paziente: Gli allievi pisani per Daniele Menozzi, ed. Andrea Mariuzzo et al. (Pisa: Edizioni ETS, 2017), pp. 221-233.

36 See APF, SC Armeni, vol. 17, fol. 620 ff. For a French translation, see also Riondel, 146147. Sebouh Aslanian very generously showed me photographs of this document and others which he found in Rome about Komitas, his trial, and his lineage.

37 An example of a widespread printed account of Komitas' martyrdom is included in Mik'ayel Ch'amch'yants', Hayots' Patmut'iwn, vol. III (Venice: Jiovanni Piats'oyi, 1786). An example of an unpublished account of Komitas' martyrdom in Armenian is British Library MS, Add. 18,956, 232b-237a. 


\section{Biography-Writing and Popular Commemoration of Komitas in Armeno-Turkish}

Komitas himself left an extensive corpus of his own writings, including an unpublished polemical work on the church conflicts of his times,${ }^{38}$ and some of his own writings and poetry were used to develop martyrologies about him. The martyrology under consideration here was written by a Mkhit'arean Catholic priest named Step'anos Avk'ereants' (known in Europe as Stefano Aucher) and published in Trieste in 1798. It was entitled, The Life and Martyrdom of God's Holy Servant ${ }^{39}$ the Priest Komitas Kömürceants, and it contains the poem quoted at the beginning of this article. The booklet is one example of an Armeno-Turkish publication made by the Mkhit'arean offshoot in Trieste that was aimed at an audience in the Ottoman Empire, and Istanbul in particular. ${ }^{40}$

From the very beginning of his work, Avk'ereants' emphasizes how Komitas came to be accepted as a holy man by multiple religious communities of Istanbul, and that his grave likewise became an ecumenical holy site. He begins his martyrology by writing,

The martyrdom of the priest Komitas came to pass in Istanbul on October 25, 1707. This holy man was accepted by God and gave a good example to men. Because of this, it's clear that from that day [of his death] until today—not only among the orthodox, but among all communities (millet)—his holy grave has become a place of visitation for every community, who all call him by the titles blessed, saint, holy man, and martyr. Many knowledgeable men have written of his martyrdom until today. ${ }^{41}$

38 National Library of France, Armenian Manuscripts, 196.

39 "God's Holy Servant" is a technical term in the Roman Catholic church, delineating a grade of saintliness (beneath that of an official saint).

40 See Aslanian, “The 'Great Schism' of 1773,” p. 89. Further examples of Armeno-Turkish works published in Trieste can be found in Hasmik Stepanyan, Catalogue of Turkish Materials Written in Armenian Letters of Armenian Manuscripts and Turkish Manuscripts in Armenian Letters: Manuscripts from "Matenadaran" in Yerevan and Mother See Holy St. Echmiadzin (Yerevan: National Academy of Sciences of Armenia Institute of Oriental Studies, 2008).

41 Avk'ereants', Allab’in aziz kulu, p. 3. "Der Gomidas Kahanaynın nahadag olması, zuhur etdi İstambol'da 1707 senede, Hogdemberin 25 inde. Bu azizin Allah'a makbul olması, ve insanlara pari ibret vermesi, bundan aşikyare görünür ki o günden ça bu günedek deyil yalınız uggaparlar içinde, ya her Milletin mabeyninde, yeraneli surp evlia nahadag ve 
In this passage-and in all Catholic writings of the period - the word "orthodox" refers, of course to the Catholic Armenians.

After beginning his martyrology with reference to the endpoint and legacy of the story, Avk'ereants' goes on to describe past research and writings about Komitas. Given that by the end of the eighteenth century, there already existed a rich tradition of writings about the Ottoman Empire's most famous ArmenianCatholic martyr, he considers it necessary to list the reasons why he would add to the literature. On this point, he writes,

Many things relating to Komitas' life and martyrdom were not related by them [previous authors]. For this reason all of their histories seem deficient. Secondly, the years were not related in those versions. For example, if we want to know [the answers to the following questions]: In what year did Komitas became orthodox; when did he go to Jerusalem; how long did he stay there; when did he versify the Acts of the Apostles; why did he recite his lamentation; how many times was he imprisoned; how long was he hidden in houses and [when] did he come forth? All of these things are either not present among the authors of the histories which we have indicated, or if it is present a bit, because it was not written with the time and year readers have misgivings. ${ }^{42}$

In short, he rejects previous histories as deficient in information and chronology, and he sets out to set the record straight by doing further primary source research and by placing his work within a strict chronology, with years given for all the events in Komitas' life. He concludes the section by justifying his use of the Armeno-Turkish language:

We compared all of them and wrote this history in order to satisfy everyone's requests. This is the reason the for our writing in common Turkish: many people

mardiros ism ile söylendikden sonra aziz Kerezmanı her Millete ziyaret yeri olmuşdur. Ve çok ilimdar ademler onun nahadagutiunu yazmışlar bu günedek.”

42 Avk'ereants', Allab’in aziz kulu, pp. 4-5. "Çok şey Der Gomidas’ın gerek varkına mütalik ve gerek nahadagutüna, onlara dakhi beyan olmamışdır. Bu ecilden cümlesinin badmutünu kusur görünür. İkinci, seneler beyan değildir ol hikeayetlerde, ne temsil bilmek isdersek hangı sene Der Gomidas uggapar olmuş, ne vakit Yerusagem'e gitmiş, ne kadar onda eylenmiş, ne vakit Kordzk arakelotsu votanavor etmiş, vogpunu ne ecilden söylemiş, kaç defa hapiz olmuş, ne kıdar zeman gizlenmiş evlerde, ve meydana çımış, bunların cümlesi ya hiç yokdur işaret etdiğimiz padmutün yazanlarda yakhot az çok varsa, vakdı ve senesi ile yazılmadığından okuyanlar fesfesede [vesvesede] kalırlar." 
requested that we write in this language so that they could understand [emphasis added.$^{43}$

As with other Armeno-Turkish sources from the Ottoman Empire, the author explicitly justifies his choice of language by reference to popular demand and comprehensibility. Although there was already a tradition of writings about Komitas, Avk'ereants' utilizes Armeno-Turkish to broaden the audience.

After this introduction, Avk'ereants' proceeds to the first chapter of the book, which contains a total of twenty-three chapters, excluding the introduction and the conclusion. He addresses Komitas' distinguished lineage, which had been established before him by scholars who had made extensive inquiries into Komitas' genealogy with diverse sources:

Finally, after asking the elderly grandchildren of Komitas and the old people who were in Istanbul and finding some things from a few books and investigating the tombstones of the lineage of the Kömürceants in Balıklı [Cemetery], they found the truth, that after 1600 in the beginning of the new century someone named Serkis from the lineage of the Kömürceants came to Istanbul from the city of Eğin. ${ }^{44}$

This refugee from Anatolia would have been Komitas' grandfather. His father was a distinguished priest in Istanbul who had been born in the midst of his family's migration away from Eastern Anatolia towards Istanbul. ${ }^{45}$ Of course the discussion of Komitas' lineage also mentions his illustrious brother Eremia.

43 Avk'ereants', Allab’n aziz kulu, p. 6. "cümlesini rubar edip bu badmutünu yazdık cümlenin arzusunu def etmek için. Bayağı Türk dilinde yazmamızın bayisi budur, ki çok kişiler kendilerinin ağnaması için, reca etdiler ki bu lisande yazalım.”

44 Avk'ereants', Allab’in aziz kulu, p. 9. “...çok zahmet çekdiler aziz nahadagın sinsilesini tekmil bulmağa biraz vakit sürdü bunların zahmeti. Encamında İstambol'da olan ihdiarlardan ve Der Gomidas'ın yaşlı torunlarından sorup sival etdigden sonra biraz kitablardan dahi şey bulup ve Balıklıda Kömürceants sinsilesinin mezar taşlarını tefdiş edip sahih buldular, ki çıkan tarın sifdahında yani 1600 seneden sonra Eğin şeherinden Serkis isminde bir kişi zade Kömürceants soyundan İstambol'a gelmiş."

45 For more about these seventeenth-century Armenian migrations, see Henry R. Shapiro, "The Great Armenian Flight: Migration and Cultural Change in the Seventeenth-Century Ottoman Empire," Journal of Early Modern History, 23 (2019): 67-89. 
Avk'ereants' goes on to describe Komitas' early childhood, seeking to demonstrate precocious signs of his saintliness. The author writes,

While still a child, some signs were seen in him that indicated the sweet glance by which our lord God looked upon and created this dear soul. His external appearance [was one of] modest and sweet glances. By nature [he was] gentle and polite. [He was] sharp of mind and so desirous of spiritual things that from every learned person he wanted to listen to intellectual conversation. However many spiritual books he read, always he made effort to grasp the idea of what he read. Because he also possessed a sweet voice, and because he said many times the spiritual hymns and odes, he learned them by heart. ${ }^{46}$

Unlike his elder brother Eremia, it was clear that Komitas' path lay with the Church, and the following chapter describes his marriage and ordination as a priest.

Later the author narrates how Komitas decided to become a Roman Catholic, or rather, in the language of the text, "orthodox." The chapter is worth citing at length because it shows how direct links between Rome and Armenian clergy in the Ottoman Empire catalyzed conversions:

The ways in which our Lord God attracts a soul to Himself leaves man in astonishment. The talents that Komitas took from the Lord our God in the works that he performed, they won the great friendship of the Catholicos of Ejmiatsin and the Pontiff of Rome. As a result in 1699 Pope Innocent XII [gave] a beautiful throne as a gift to Catholicos Nahabed. In 1698 on May 8, Melkiset vartabed, named Subhi, became patriarch in Istanbul. He was the patriarch for fifteen months, and he preached orthodoxy. Not being satisfied with this, he also had the rites in churches performed in accordance with orthodoxy. In 1699 on July 23 they removed Melkiset from the throne and made Mkhitar vartabed of Kurdistan the [new] patriarch. He also went by the road of Melkiset, such that in the days of these two patriarchs the great vartabeds would preach and perform the mass in either the Church of the Holy Mother or in the St. George Church.

46 Avk'ereants', Allah’in aziz kulu, pp. 10-11. "Daha çocugiken bazi nşaneler göründü üzerinde, ki beyan ider idi nice Allah efendimiz tatlı nazar ile bakıp yaradmışıdı bu aziz canı. Ardakin sıfatı bargeşd ve tatlı bakışlı, tabietce milayım ve kagakavar, zeyn açıklığı ale, ve hogevor şeylere ol kıdar havesli ki her alim kişiden bir alim söhbet işitmek arzusinde idi ve ne kıdar hogevor kitabler okursa dayma okuduğunu fikrinde zapd etmeğe çabalarıdı ve birde tatlı sese malik olduğundan hogevor Şaraganları ve Dagları çok defa söylediğinden ezber öğrenmiş idi." 
One of these was the famous Arakelean Khachadur vartabed from Erzurum. ${ }^{47} \mathrm{He}$ was a student of the school known as Propaganda [i.e., the Collegio Urbano in Rome]. This Khachadur vartabed was the one who brought the above-mentioned throne to Catholicos Nahabed. It is known from his books that he was a learned man, [and] he was also the dear friend of Abbot Mkhitar. In those days Abbot Mkhitar was in Istanbul, and he would preach in the churches. From the time of his childhood, Komitas had been given a desire to meet with scholars and to learn knowledge from them. From such scholars he quickly took an example. Whatever was contrary to the Roman doctrine, he left all of it. After accepting orthodoxy, he began to preach to the people, as is very clear in these words from the decree of the Molla of Galata: "He left the Armenian rite and entered the Frankish religion. He performed the Frankish liturgy and led many astray, and he has been a cause for leading the Armenian millet astray." We will see all of this decree in the eighteenth chapter. ${ }^{48}$

47 For more on Khachadur, see François Tournebize, “Araqélian Khatchatur," Dictionnaire d'Histoire et de Géographie Ecclésiastique (Paris: Letouzey et Ané, 1912), pp. 1436-1438.

48 Avk'ereants', Allab’n aziz kulu, pp. 12-13. "Allah efendimizin yolları bir canı kendine çekmede, taacübda brakır insanı. Der Gomidas Allah efendimizden aldığı dağantları işletdiği esirlerde, Yeçmiadzin Gatugigos’u ile Hroma Hayrabedi böyük bir dosdluk ederler, şöyle ki on ikinci Yennovgendios hayrabedden güzel bir ator peşgeş olunur Nahabed Gatogigos'a 1699 senede. 1698 senede de Mayis'in 8 inde Subhi naminde Melkiset vartabed Badriark olur İstambol'a. On beş ay badriarklık edip uggaparutün karozel eder, ve buna kanahat [kanaat] etmeyip ararogutünları dakhi uggarparca yürüdür jamlarda. 1699 senede Yulisin 23 ünde Melkiset’i atorundan düşürüp kürdisdanlı Mkhitar vartabedi Badriark ederler. Bu dakhi Melkiset'in yolunca gider şöyle ki bu iki badriarkların gününde böyük vartabedler gerek Asduadzadz'in jamında, ve gerek Surp Keork jamında hem karoz verirlerdi hem Badarak ederlerdi.

Bunların birisi namdar Erzürümlü Arakelean Khaçadur vartabed idi Propaganda tarif olan tbradun uşağı. Bu Khaçadur vartabed idi Nahabed Gatogigos'a zikr olan atoru götüren, ve alim adem olduğu kitablarından malim oldukdan made Mkhitar Abbay'nın dakhi sireli dosdu idi, ve Mkhitar Abbay'da bu günlerde İstambol'da idi, ve jamlarda karoz verir idi. Der Gomidas'a ki çocuklukdan pari haves verilmiş idi alimlerle görüşmek, ve onlardan imasdutün öyrenmek, tez vari böyle alimlerden ibret alıp ne kıdar Hroma vartabedutünuna karşı şey varısa cümlesini brakıp uggaparlığı kabul etdikden sonra başladı jogovurtuna dakhi karozel etmeğe, nice Kalata Mollası'nın ilamından aşikyare görünür bu sözlerinde. "Meshebi Ermeni'den khuruc ve dini Efrence dukhul, ve ayni efrenci icra, ve niçesin dakhi izlal, ve Millet'i ermeni'yi izlale bayis olup, yev ayln.” Bu ilamın tekmilini görürüz on sekizinci babde." 
Here we see explicit reference to a student from the school Propaganda Fide, the Collegio Urbano in Rome, and the impact he was having in Istanbul. At the end of the passage Avk'ereants' quotes from the Ottoman court record of Komitas' trial, promising to offer a complete Armeno-Turkish version of it in a later chapter. The document was important to Avk'ereants' because it bolstered Komitas' qualifications for beatification in the Catholic Church.

At the time when Komitas converted to Catholicism, political conditions allowed for extensive freedoms for Catholics. In the words of Avk'ereants', “... [one] would have supposed that in a little bit of time the whole community (millet) would accept openly the Roman confession." ${ }^{49} \mathrm{He}$ describes how at that time-in 1701-Catholic books translated from French into Armenian began to circulate widely in Istanbul, so much so that "they were found on the breast of all." ${ }^{50}$ In the eyes of Avk'ereants', this imprudent level of permissiveness made conflict inevitable.

Indeed, the atmosphere soon changed drastically, and in subsequent chapters of his life of Komitas, Avk'ereants' discusses in detail anti-Catholic persecutions at the hands of the Armenian Church, which worked in league with the Ottoman state to limit Catholic influence in the Ottoman Empire. Avk'ereants describes how the anti-Catholic Patriarch Ep'rem assumed the patriarchal throne, systematically sought out influential Catholics like Mkhitar, and collaborated with the Ottoman state to have Catholic-leaning priests and laymen punished:

...they seized and threw to the galleys both priests and laymen haphazardly. This persecution began in 1701 in the month of September. Patriarch Eprem wanted to give over Khachadur vartabed, but he was unable. He sought Abbot Mkhitar and wrote official letters (tezkere), but he couldn't catch him in his trap. The priest Komitas saw that there was no means of security for himself besides flight. $\mathrm{He}$ boarded a ship, fled, and went to Jerusalem. ${ }^{51}$

49 Avk'ereants', Allah’ın aziz kulu, p. 14. "Şöyle ki zann olunurdu az vakitde bütün Millet Hroma davanutünu aşikyare kabul idecek."

50 Avk'ereants', Allab'in aziz kulu, p. 14. "Cümlesinin koynunda bulunurdu." For more about these printing efforts, see Raymond H. Kévorkian, "L'imprimerie Surb Ejmiacin et Surb Sargis Zōravar et le conflit entre Arméniens et catholiques à Constantinople (1695-1718)," Revue des études arméniennes, 15 (1981): 401-416; and Santus, Trasgressioni necessarie, pp. 320-324.

51 Avk'ereants', Allab’n aziz kulu, pp. 15-16. "İmdi yeni Badriarka arka verip böyük bir haladzank açdılar İstambol'un içinde, ve rasd geleni kahanaylardan ve aşkharhaganlardan tutdurup atdılar küreye. Bu haladzank başladı 1701 senede Sebdemper ayında. Eprem Badriark 
Though Komitas fled to Jerusalem, he was not to find peace there, and he ultimately returned to his hometown of Istanbul. There he entered into hiding because the reigning Armenian patriarch Awetik' was an enemy of Catholics. Komitas endured several rounds of living in hiding, during which time he wrote poetry and lamentations, one of which is quoted at the beginning of this article.

Finally, in 1707, during the time of the Armenian Patriarch Sahak, some Apostolic Armenian clergy obtained permission from the Ottoman state to raid Komitas' house and have him imprisoned. His allies were able to spend some money and have him released, but it was only a temporary relief. On September 5, 1707, a more determined Armenian patriarch came to the throneHovhannēs of Izmir - and he maneuvered to have Komitas arrested for a final time. Hovhannēs was the former deputy of Awetik', and tensions had reached such a height because Awetik' had been kidnapped at the order of the French ambassador, in response to the fervor of his anti-Catholic activities. ${ }^{52}$ Avk'ereants's account of Komitas' final days was clearly designed to mimic the Passion of Jesus and of many Christian martyrs who had come before. He describes how the patriarch was personally present at Komitas' house for the arrest, and he subjected him to humiliations. According to Avk'ereants',

In the night at three a.m. Patriarch Yohannes with his priests and students changed their clothes and went to Komitas' door with policemen. Upon arrival, they demanded Komitas. Before God's holy servant opened the window and replied, they forced the door and opened it. When they entered inside, Komitas met them and said, "I am Komitas."

When he said this, Patriarch Yohannes angrily struck the saint's face two times, with the result that he uprooted two of his teeth. They held him by the collar and took him out of the house. While taking and bringing him to prison, they passed the gate of the priest called "Pine Nut." After having a few drinks there and enjoying themselves, they began to make fun of God's servant. Everyone can understand the sort of inappropriate conversation which takes place at such meetings and what kind of means are employed to make the innocent suffer with hurtful words. After enjoying themselves a bit there, they brought him to Mönzür Agha Prison and handed him over. With the intention of bringing him

isterdi Khaçadur vartabedi ele getirmeğe, lakin kabil olmadı. Mkhitar Abbay’ı çok aradı ve tesgereler yazdı, lakin duzağa düşüremedi. Aziz Der Gomidas kahana gördü ki kendine bir türlü selamet yolu yok kaçmaden made, bir gemiye girip kaçdı Yeresugem'e gitdi.”

52 See Santus, "The Şeyhülislam, the Patriarch and the Ambassador," p. 11. 
to the vizier's meeting on the next day, Wednesday, they went off to rest. Komitas endured this much torture with patience. He would pray to God and many times he said this: "Lord, don't count this a sin for them, as they know not what they do" (Luke 23:34). ${ }^{53}$

After describing Komitas' humiliation at the hands of the Armenian patriarch and his priests, Avk'ereants' proceeds to narrate his trial, making clear allusions to Christ before Pontius Pilate. Komitas' first hearing was before the grand vizier of the Ottoman Empire, and the Armenian patriarch used the hearing to accuse of Komitas of political treason, saying,

Some of the Armenians are following the Frankish confession and have gone against the confession of their ancestors. Uniting with the Franks, they have become rebels against the Ottoman state, and they are inciting their community to revolt. The head of this group is Father Komitas. If he is not punished, the entire community will be lost. For this reason the Armenian patriarch requests in the name of the community that he and those like him be removed from the world, so that the rest of the community will be loyal subjects of the state. ${ }^{54}$

53 Avk'ereants', Allah’ın aziz kulu, p. 29. “...aziz Der Gomidas kahanaynın üzerine, imdi gecenin sahat üçünde kendisi Yohannes Badriark Derderler ile ve aşkharhaganlar ile tepdili kıyafet zabit ademleri ile Der Gomidas'ın kapusuna varıp Der Gomidas'ı isdediler. Allah'ın aziz kulu pencereyi açıp cevab verinceye dek kapuyu zorlayıp açdılar ve içeri girdiklerinde Der Gomidas bunları karşılayıp dedi, Der Gomidas benim. Bunu der iken Yohannes Badriark örke ile iki sille vurdu azizin yüzüne şöyle ki iki dişini yerinden sökdü ve yakasından tutup evden dışarı çıkardılar. Ve alıp götürürken hapize Çamiç fındık tabir olan Derderin kapusundan geçer iken onda içgi getirtdirip keyflerini çatdıkdan sonra başladılar zefke almağa Allah'ın kulunu her kişi ağnayabilir ne tarz yolsuz söhbetler olur öyle bir meclisde ve ne türlü can acıdacak sözler ile ciyerini yakmaya günahsızın yollar kullanılır. Biraz onda eylendikden sonra götürdüler Mönzür Ağa hapizine teslim etdiler ve ırahatlanmaya gitdiler, ertesi gün Çarşamba vezir divanına çıkarmak niyeti ile Der Gomidas bu kıdar işgenceyi sabrile çekip Allah'a duva iderdi ve çok defa bunu söylerdi. Der mi hamarir sotsa zays megs, zi voç kiden zinç kordzen.”

54 Avk'ereants', Allah’n aziz kulu, p. 30. "Bazileri Ermenilerden, Efrenc mesebine sülük edip ata u dedelerinin mesebine karşı olmuşlar ve Frenglerle bir olup Osmanlı devletine ası olmuşlar ve cemaheti dakhi ası ediyorlar. Bunların cemahet başısı papa Gomidas'dır. Eğer bunun hakından gelinmezse bütün Millet elden gider bu ecilden Ermeni Patrigi milletce reca eder bunun ve buna benzerlerin dünyadan vicudini kaldırmağa ki kusur millet sadikane reya olsun devlete." 
Komitas denied these accusations, and the grand vizier, being uncertain, decided to seek the legal opinion, a fetva, of the Şeyhülislam, the grand mufti of the Ottoman Empire. The Şeyhülislam did not issue an opinion, arguing that it was not the place of the state to interfere in the internal affairs of Christians, almost letting Komitas off the hook. The grand vizier proceeded, however, to refer the case to the "Molla of Galata," and Avk'ereants' claims that bribes influenced the molla's decision to hear the case. Avk'ereants' includes an Armeno-Turkish version of the actual Ottoman court record of the case in his martyrology. ${ }^{55}$

Finally, Avk'ereants' narrates how Komitas was formally condemned to death. He writes that besides from the day which it took place, "Komitas' imprisonment, humiliation, and his being brought to the gates of the officials was just like our lord Jesus' tortures..." ${ }^{56} \mathrm{He}$ depicts the grand vizier as placing the moral weight of the unjust decision on the shoulders of the Armenian patriarch. ${ }^{57}$ According to the text, the vizier explicitly said this to the patriarch, who consented, in the following exchange:

... [the Vizier] said to the patriarch: "May this priest's blood be on your head." At this statement, the patriarch and the priests said "Yes, my lord, may it be a good deed for you, and may the sin of his blood be on our head[s]." ${ }^{58}$

After receiving his death sentence, Komitas was handed over the executioner. The Grand Vizier-who supposedly felt guilt at condemning an innocent manurged a bodyguard to try to convince Komitas to convert to Islam and thus to save his life, but Avk'ereants' depicts Komitas as being eager for Christian martyrdom. Avk'ereants' relates the moment of execution on October 25, 1707, which was supposedly followed by a miraculous change of weather. ${ }^{59}$

55 Avk'ereants', Allah'in aziz kulu, pp. 32-34.

56 Avk'ereants', Allab’ın aziz kulu, p. 35. "Çünki Der Gomidas'ın tutulması, irezil olması, zabit kapularına götürülmesi, tıbkı Yisus efendimizin çarçaranklarına beynzer..."

57 For an account of the development of the literary treatment of Komitas' trial and this casting of the responsibility on the Apostolic patriarch in previous narratives, see Santus, "Un beato martire," pp. 240-241.

58 Avk'ereants', Allab’ın aziz kulu, p. 36. “...dedi Badriarka: Bu papazın kanı senin başına olsun. Bu söze Badriark, ve Derderler beli efendim sevabı sana olsun, ve kanı mabalı bizim başımıza olsun, dediler."

59 Avk'ereants', Allab'in aziz kulu, p. 38. 
Ultimately, Komitas was buried in the Armenian Balıklı Cemetary, where his tombstone remains to this very day. In the introduction of his martyology Avk'ereants' emphasized that Komitas' gravesite was already holy "not only among the orthodox, but among all communities (millet)." ${ }^{60} \mathrm{He}$ reiterates this point in the conclusions, describing "how [Komitas'] grave became a place of visitation (ziyaret) for the Istanbul communities." ${ }^{\prime 1}$ The research of Santus outlines the process by which the Roman Catholic Church would later beatify Komitas.

In sum, Avk'ereants' composes a martyrology influenced both by past models_including the Gospels_ and also by historical research using both primary and secondary sources on Komitas' life. He composes his synthesis in a register of Armeno-Turkish prose which is syntactically close to the spoken language of seventeenth-century Istanbul, as opposed to rarified literary Ottoman Turkish. Moreover, he used many Armenian words in the course of his Turkish narration that would be familiar to Turkophone Armenians, but not to Muslims, thus showing that his audience was Christian. Through Avk'ereants's efforts, Komitas's life and execution became accessible to the numerous Armenian Christians of Istanbul and the Ottoman Empire who could not read Classical Armenian, and the pamphlet was likely both read in private and aloud by the growing number of Armenian Catholics in the empire. It may therefore have played some role in augmenting the place of Komitas' burial spot on the map of Istanbul holy sites, a development already noted in the pamphlet. Literary and epigraphic evidence suggests that Komitas' grave would remain a site of veneration throughout the eighteenth and nineteenth centuries.

\section{Komitas' Tombstone Becomes a Saint's Shrine}

Avkereants' Armeno-Turkish martyrology is not the only source that mentions how Komitas' tombstone became a site of veneration for diverse religious communities in Istanbul. In 1844 Catholics in Galata published a polemical work in Armeno-Turkish entitled, An Armenian from Van and a Protestant Missionary, ${ }^{62}$

60 Avk'ereants', Allab’ın aziz kulu, p. 3. “...deyil yalınız uggaparlar içinde, ya her Milletin mabeyninde..."

61 Avk'ereants', Allab'in aziz kulu, p. 41. "Ve nice ilk kelamımızda tarif etdik Kerezmanı ziaret yeri olmuşdur İstambol cemahetine...”

62 Vanlı Bir Ermeni ile Protestant Karoziç (Galata: St. Benedict Printing House, 1844). For more about this text, see Johann Strauss, "Is Karamanli Literature Part of a 'ChristianTurkish (Turco-Christian) Literature?" in Cries and Whispers in Karamanlidika Books, ed. Evangelia Balta and Matthias Kappler (Wiesbaden: Harrassowitz Verlag, 2010), p. 169. 
a long discussion about religious questions between Ottoman Armenians and a Protestant missionary. The discourse depicts Protestants in an unsympathetic light and is a clear response to Protestant missionary efforts in Anatolia aimed at the conversion of Armenians. ${ }^{63}$ In one chapter of the discourse, the author relates how a wealthy Armenian saw a servant of his present at Komitas' grave on the saint's day. In the course of his narration and the subsequent discussion, the text conveys much about how Komitas' grave had developed into an ecumenical shrine.

The author begins by explaining that "Yesterday was Rev. Komitas' day, and in accordance with old custom, a very big crowd gathered at the Balikli Cemetery." ${ }^{64}$ After explaining how he caught sight of his Armenian servant girl, he recounts how he scolded her later on at his home, exclaiming,

How strange! To join with Catholics, to go visit graves, and to pray....according to what the Protestant missionaries have taught [us], isn't this the highest degree of idolatry and polytheism? Do you think that the dead can still be of benefit to the living, and that the soil of their decayed bones hears your prayers? ${ }^{65}$

The servant girl defends herself, explaining that all Armenians revere Komitas, and that she went to the grave to ask for his intercession on behalf of a sick friend:

I believe-along with all Armenians—-that our father Rev. Komitas reached the eternal glory of heaven. I requested to God that He be a healer, so that our son Ohannes, who has been suffering from malaria for a month, be cured. ${ }^{66}$

63 For more about Protestant missionary activities in the nineteenth-century Ottoman Empire, see Yaşar Tolga Cora, "Localizing Missionary Activities: Encounters Between Tondrakians, Protestants, and Apostolic Armenians in Khnus in the Mid-Nineteenth Century," in The Ottoman East in the Nineteenth Century: Societies, Identities and Politics, ed. Yaşar Tolga Cora, Dzovinar Derderian and Ali Sipahi (London: I.B. Tauris, 2016), pp. 109-132; and Anna Ohanjanyan, "Evangelical and Pentecostal Communities in Armenia: Negotiating Identity and Accommodation," in Armenian Christianity Today: Identity Politics and Popular Practice, ed. Alexander Agadjanian (London: Ashgate, 2014), pp. 91-124.

64 Vanl Bir Ermeni ile Protestant Karoziç, p. 179. "Dün Der Gomidas'in günü idi. Ve adeti kadime üzre Balıklı mezarlığına ifrat çok kalabalık toplandı.”

65 Vanl Bir Ermeni ile Protestant Karoziç, p. 180. "Acayip! Katolikler ile bir olup de mezarler üstüne ziyarete gidip dua etmek, Protestant karoziçlerin öyretdikleri üzre Putperestliyin ve Avelortabaşdutün'un son derecesi deyil mi dir? Ağnaşılan hala o ölülerin dirilere faydası olabilir, ve onların çürümüş kemiklerinin toprağı senin dualarını işidir iddasında mısın?"

66 Vanlı Bir Ermeni ile Protestant Karoziç, p. 181. "Ben cemii Haylar 1la Der Gomidas 
The text proceeds to explain how her master mercilessly sent her away from his house. In response to this story, one of the other interlocutors in the discussion expresses sympathy for the poor girl, saying

My friend, is it really an offence to be found in the crowd of Catholics and [in their] adornment? You should know that on that day even Greeks (Urumlar) and Turks (Dacigler) join, and they take from the ground of the martyr [with] due observances as if it was a relic. ${ }^{67}$

While the details of the discourse between Apostolic, Catholic, and Protestant Armenians from this 1844 Armeno-Turkish text lie outside the topic of this article, in the course of their argument they substantiated other texts' claims that Komitas' grave had become an ecumenical shrine, and even a source of healing, for Istanbul Armenians-Catholic and Apostolic alike-and even Greeks and Turks as well. Given the alleged responsibility of the Apostolic patriarch for Komitas' execution, it might seem contradictory that Apostolic Armenians would celebrate his martyrdom. There were, however, various traditions for interpreting Komitas, ranging from his being a Catholic martyr as depicted by Avk'ereants', to his becoming over time an "Armenian" national martyr. ${ }^{68}$ This text shows how he had become a saint for "all Armenians," not just Catholic ones, part of a shift from a confessional basis of Armenian identity to a nationalistic one. ${ }^{69}$

Yet another source which confirms this picture of Komitas' grave as a site of veneration and pilgrimage is Komitas' tombstone itself. As of September 2019when the present author visited-Komitas' tombstone was still preserved at the Balıklı Armenian Cemetery in Zeytinburnu, İstanbul, and its full transcription and translation can be found at the end of this article in Appendix II. The poetic verses on the tombstone explicitly refer to how it had become a site of visitation. It states that

babamızın göylerin ebedi parkına vasıl olmuş olduğuna iman getirip ve bir aydan beri sıtmadan eriyip kharab olmuş olan oğlumuz Ohannes’in şifa bulması için Tanrı'ya şifayetci olmasını reca ederim.”

67 Vanl Bir Ermeni ile Protestant Karoziç, p. 182. "Ey dosdum, ehlin Katoliklerin kalabalığında ve ziynetinde bulunmasıyla kabahatlı mı olmuş oluyor. Bilmelisin ki o gün Urumlar ve Dacigler bile kalabalığa karışıp Nahadag’ın toprağından dakhi rayete şayeste bir Masunk gibi alırlar."

68 For exploration of these interpretations, see Santus, “Un Beato Martire,” p. 230-233.

69 Sebouh Aslanian analyzes this shift in his forthcoming book, Global Early Modernity and Mobility: Port Cities and Printers in the Armenian Diaspora, 1512-1800. 
Komitas the great atoner dressed in light, At the Parmak Gate near to the Bayezid [Mosque]

On the feast of Demetrios he was decapitated

On Monday he was placed in this tomb

Komitas the great martyr, with solemnity

Signs of miracles multiplied in number

Of which the testifier is the sea of pilgrims.

Flowing always around the tomb of the saint

Komitas the great martyr, highly praised

[The martyrdom] was completed in the year of Christ

The thousand seven-hundred and seventh (1707). ${ }^{70}$

This explicit reference to the "sea of pilgrims/Flowing always around the tomb of the saint" implies that the place of Komitas' burial had already become a holy site before the tombstone was erected. The erection of the tombstone seems to have occurred some time after Komitas' execution and burial, and the decision to formally memorialize him was probably encouraged by writings about Komitas, perhaps even Avk'ereants"s Armeno-Turkish tract.

In summary, both Armeno-Turkish and Armenian primary sources show how Komitas had unified two aspects of the religious landscape of early modern Istanbul, being a Christian "neo-martyr" whose grave developed into a site of veneration, like those described in the seventeenth century by Evliya Çelebi and Komitas' own brother Eremia. Because Komitas was a Catholic martyr, his veneration did not remain limited to Istanbul, but rather his story was the topic of research among Catholics in Rome and the Vatican, where Komitas was officially beatified.

\section{Conclusions}

This article has shown how Komitas enjoyed a long afterlife in Ottoman Istanbul, pulling together, disparate trends in Ottoman religious history, with a Catholic twist. Firstly, Komitas was a "neo-martyr," an Ottoman Christian killed for his faith. Whereas most tales of such martyrs in Armenian and Greek place the blame on the Ottoman state, Komitas' story diverges from the genre, as his

70 See Appendix II. 
execution was instigated by the Armenian Patriarchate, not by Muslims, as part of a broader campaign by the patriarchate to use mechanisms of the state to clamp down on-and sometimes torture, enslave, and even kill—Armenian Catholics. Secondly, his tomb became a holy site for Armenians of all denominations, and, according to several accounts, for Greeks and Muslims as well, thus adding a link in a long history of ecumenical holy spaces with deep roots in the history of Anatolia. Moreover, his life story and memory circulated in Ottoman Istanbul and beyond thanks to the literary endeavor of a Catholic author writing in ArmenoTurkish, the language of choice for anyone who wanted to reach the broadest reading audience among Ottoman Armenians, particularly Armenian Catholics.

Armenian Catholics in the Ottoman Empire would finally come "out of the closet" in 1830, with the official recognition of their millet by the Ottoman state. They played a crucial role in the cultural and economic life of the empire, producing many influential merchants, state servants, and authors, such as the novelist Vartan Pasha, who is considered by some to have published the first Turkish novel using the Armenian alphabet in $1851 .^{71}$ While late Ottoman historians are aware of these rich contributions in the nineteenth century, the Armenian Catholic history in the early modern period remains largely in the shadows. The aim of this article has been to cast light on the life and afterlives of one early modern Armenian Catholic luminary, showing how his history and that of his commemoration were deeply connected to broader themes in Ottoman cultural history.

Afterlives of Komitas K'eōmurchean (1656-1707): Commemorating an Istanbul-Armenian Martyr in Armeno-Turkish Literature and Sacred Pilgrimage

Abstract - Komitas K'eōmurchean (1656-1707) was an Armenian priest from Istanbul and the younger brother of the prolific writer Eremia K'eōmurchean. While Eremia was an Apostolic Armenian layman, Komitas was a clergyman known for his Catholic teachings, which brought him into conflict with leading Apostolic churchmen. Ultimately, he was sentenced to death before an Ottoman court and executed. After his death, Komitas' grave became a site of ecumenical veneration for Armenians of all denominations, along with some Greeks and Muslims. This article describes how Komitas was commemorated after his death in Armeno-Turkish literature (Turkish written in the Armenian alphabet), and it presents transcriptions and

71 Vartan Paşa, Akabi Hikayesi: İlk Türkçe Roman, 1851, ed. Andreas Tietze (İstanbul: Eren, 1991). 
translations of the Ottoman court record of Komitas' trial and of his tombstone's Armenian inscription. The article sheds light on Armenian Catholic history in the early modern period, and it contextualizes Komitas' life and the events after his death among broader trends in Ottoman cultural history, namely "neo-martyrs" and sites of sacred pilgrimage.

Keywords: Komitas K'eōmurchean, Eremia K'eōmurchean, Armeno-Turkish, NeoMartyrs, Armenian Catholics, Ecumenical Holy Sites, Confessionalization. 


\section{Appendix I:}

Komitas Trial Sicil: Galata Şer'iyye Sicilleri (GŞS) 202, 44b-45a $a^{72}$

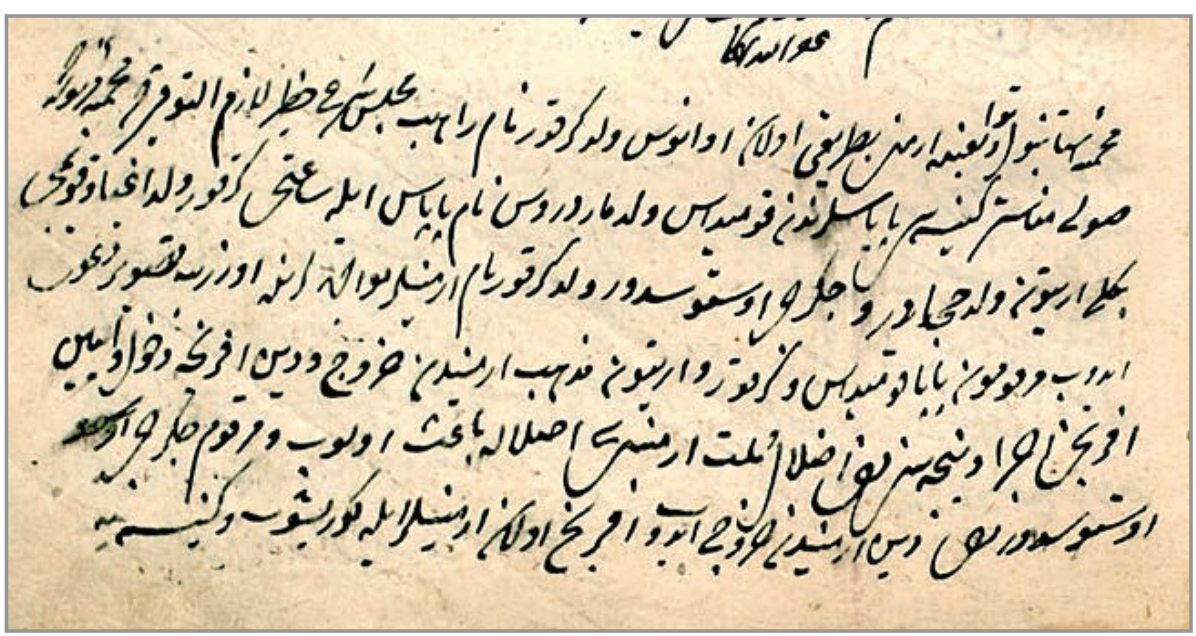

$44^{\mathrm{b}}$

72 I accessed this document at the Center for Islamic Studies (İSAM) in Üsküdar, İstanbul. As ever, I'm grateful to the institute and its staff for their kind assistance. 


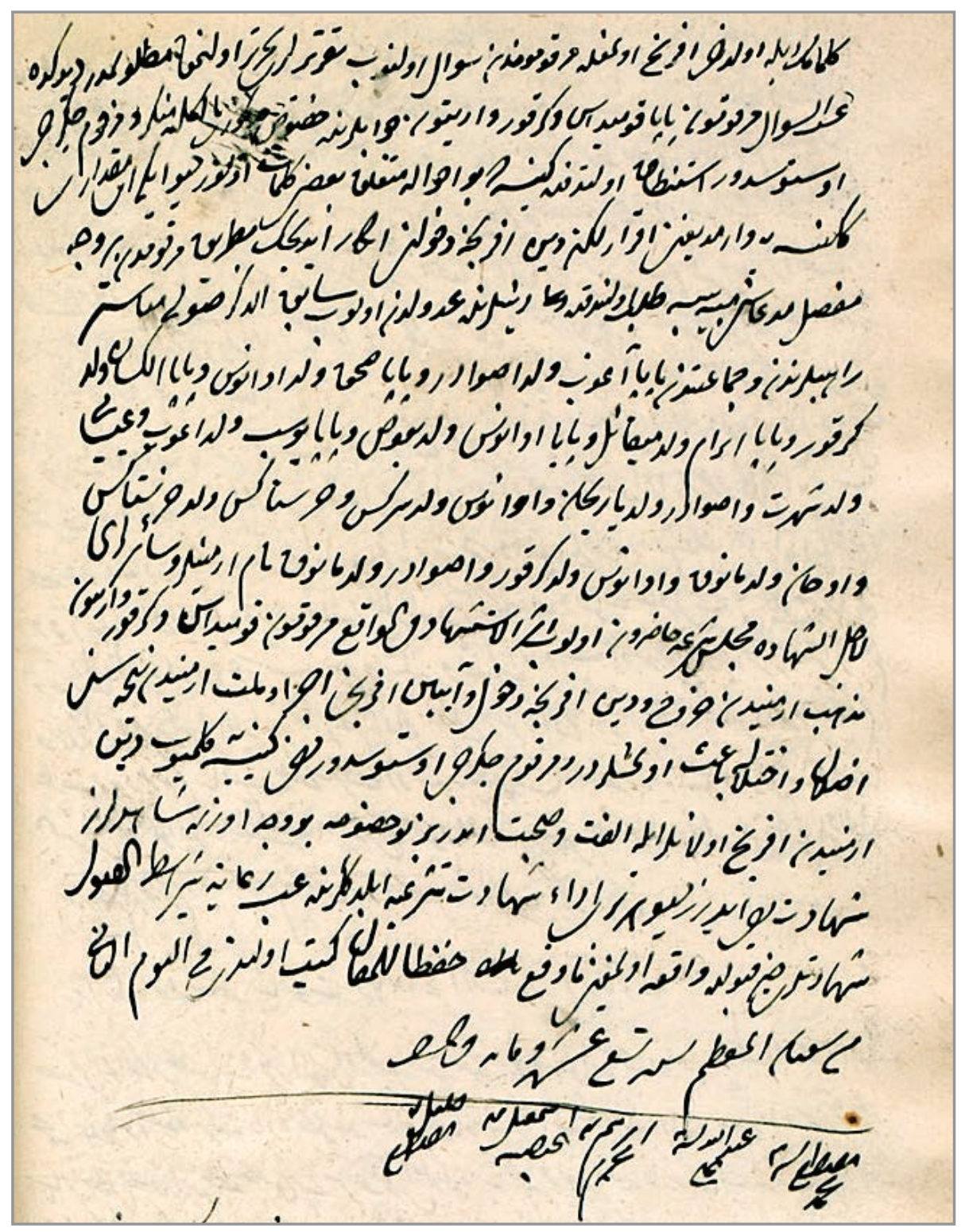

$45 a$ 


\section{Ottoman Turkish Transcription}

1. Mahmiyye-i İstanbul ve tevâbi'inde Ermeni Patriği olan Avanos veledi Krikor nâm râhib meclis-i şer'-i hatîr-1 lâzımü't-tevkîrde mahmiyye-i mezbûrede

2. Sulu Manastır kenîsesi papaslarından Komidas veled-i Mardiros nâm papas ile sâ‘atçi Krikor veled-i Agia ve kuyumcı

3. Benli Ariton veled-i Haçador ve ciğerci Ustosdor veled-i Krikor nâm Ermeniler muvâcehelerinde üzerine tasvîr-i da'vâ

4. idüp merkûmûn Papa Komidas ve Krikor ve Ariton mezheb-i Ermenî̀den hurûc ve dîn-i Efrenc'e duhûl ve âyîn-i

5. Efrenc'i icrầ ve nicesini dahi idlâl ve millet-i Ermenîyi ihtilâle bâ‘ is olup ve merkûm çiğerci

6. Ustosdor dahi dîn-i Ermenî̀den hurûc idüb Efrenc olan Ermeniler ile görişüp ve kenîseye

7. gelmemek ile ol-dahi Efrenc olmağla merkûmûndan su'âl olunup takrîrleri tahrîr olunmak matlûbumdur didükde

8. gıbbe's-su'âl merkûmûn Papa Komidas ve Krikor ve Ariton cevâblarında husûs-1 mezkûru bi'l-külliyye münkir ve merkûm ciğerci

9. Ustosdor istintâk olundukta kenîsede bu ahvâle müte'allik ba'z-1 kelimât olunur deyü iki ay mikdârı

10. kenîseye varmadığın ikrâr lâkin dîn-i Efrenc'e duhûlın inkâr idecek patrik-i merkûmdan ber-vech-i

11. mufassal müddeâsını mübeyyine beyyine taleb olundukda dînlerinde 'udûlden olup sâbıku'z-zikr Sulu Manastır

12. Ermenîleri'nden ve cemấatinden Papa Agob veled-i Asvador ve Papa Sahak veled-i Avanos ve Papa Aleksan veled-i

13. Krikor ve Papa Abram veled-i Mikail ve Papa Avanos veled-i Bogos ve Papa Yoseb veled-i Agob ve 'İsâyi

14. veled-i Şöhret ve Asvador veled-i Yarican ve Avanos veled-i Serkis ve Hristakes veled-i Hristakes

15. ve Ohan veled-i Manuk ve Avanos veled-i Krikor ve Asvador veled-i Manuk nâm Ermenîler ve sâirleri 
16. li-ecli'ş-şehâde meclis-i şer'e hâzırûn olup isrü̉l-istişhâd fi'l-vâki‘ merkûmûn Komidas ve Krikor ve Ariton

17. mezheb-i Ermenîden hurûc ve dîn-i Efrenc'e duhûl ve âyîn-i Efrenc’i icrầ ve millet-i Ermenîden nicesin

18. ıdlâl ve ihtilâle bấis olmuşlardır ve merkûm ciğerci Ustosdor dahi kenîseye gelmeyüp dîn-i

19. Ermenî̀den Efrenc olanlar ile ülfet ve sohbet ider biz bu husûsa bu vech üzre şâhidlerüz

20. şahâdet dahi iderüz deyü her biri edâ-yı şehâdet-i şer iyye eyledüklerinde gibbe ri'âyete şerầitü’l-kabûl

21. şehâdetleri hayyiz-i kabûlde vâkı́a olmağın mâ-vaka'a hıfzen li’l-makâl ketb olundı fi'l-yevmi's-sâmin

22. min Şa'bâni'l-mu'azzam sene tis'a 'aşere ve mi'e ve elf

23. Mustafâ Beşe bin Mehmed, 'Abdullâh beşe bin Alî, İbrâhim bin Muharrem, İsmâ'il bin ('Îsâ?), Halîl bin Mustafâ

\section{English Translation}

In the city of Istanbul and its environs, the priest named Ovannes son of Krikor, who is the Armenian patriarch, made a case in the sharia court-which must be held in reverence-before [these] named Armenians: from the priests of the the Sulu Manastır Church in the above-mentioned city the priest Komitas son of Martiros, the clock-maker Krikor son of Agia, the goldsmith Benli Ariton son of Hachatur, and the liver-salesman Ustosdor son of Krikor. He said, "I demand that the above-mentioned priest Komitas, Kirkor, and Ariton be asked and a deposition drafted from the above-mentioned [concerning] whether they have left the Armenian rite and entered the Frankish religion and performed the Frankish liturgy and led many astray and been a cause for leading the Armenian millet astray, and if the above-mentioned liver salesman Ustosdor has left the Armenian religion and met with Armenians who have become Franks, and if he was not coming to church and has also become a Frank." After being asked, the above-mentioned Father Komitas and Kirkor and Ariton in their answers about the above-mentioned topic entirely denied it. Upon questioning, the above-mentioned liver salesman Ustosdor said some words relating to the situation in the church. When he admitted that he hadn't been to church in two months but 
denied that he had entered the Frankish religion, it was demanded by the abovementioned patriarch detailed proof declaring the assertion. From the just men in their religion of the priests and community of the previously mentioned Sulu Manastır the Armenians named Father Agob son of Asvador and Father Sahak son of Avanos and Father Aleksan son of Kirkor and Father Abram son of Mikael and Father Avanos son of Bogos and Father Yoseb son of Agop and Isayi son of Şöhret and Asvador son of Yarican and Avanos son of Sarkis and Hristakes son of Hristakes and Ohan son of Manuk and Avanos son of Kirkor and Asvador son of Manuk and others for the sake of giving testimony were present at the sharia court. By way of giving witness, every one of them gave testimony in accordance with the sharia saying that "In fact the above mentioned Komitas and Krikor and Ariton have left the Armenian rite, entered the religion of the Franks, and performed the Frankish liturgy. They have led many from the Armenian millet astray, and they have been a cause of sedition. And the above-mentioned liver salesman Ustosdor also doesn't come to church, and he consorts and converses with those who [have left] the Armenian religion and become Franks. On this topic in this way we are witnesses and give testimony." After observing the conditions of acceptance, when their testimonies were accepted, it was recorded on the eighth day of the great month of Şa $a^{\prime} b \hat{a} n$ in the year 1119. [Witnesses:] Mustafâ Beşe son of Mehmed, 'Abdullâh Beşe son of Alî, İbrâhim son of Muharrem, İsmâ'il son of ('Îsâ?), Halîl son of Mustafâ 


\section{Appendix II:}

Komitas' Tombstone, Located in the Balıklı Armenian Cemetery in Zeytinburnu, İstanbul, September $2019^{73}$

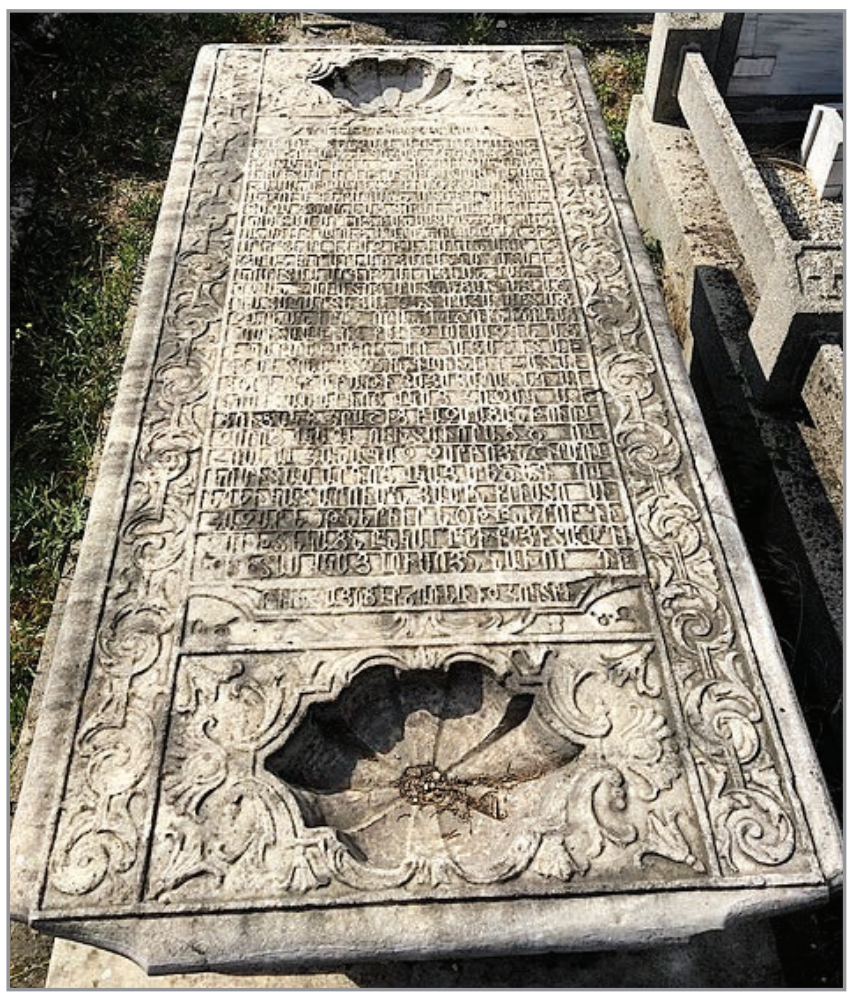

73 An early twentieth-century photo of Komitas' tombstone from a greater distance and sideways angle may also be found in T'orosean, Vark' Mkhit'aray abbayi Sebastioy, 230. 


\section{Armenian Transcription $^{74}$}

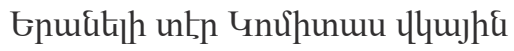

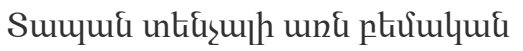

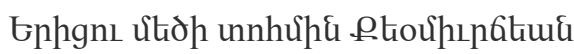

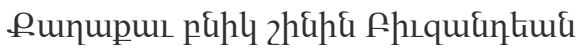

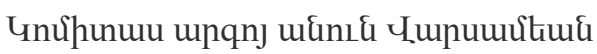

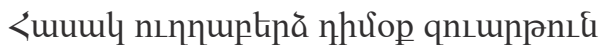

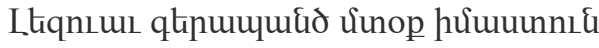

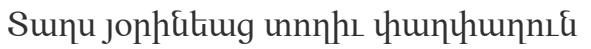

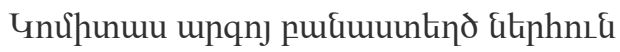

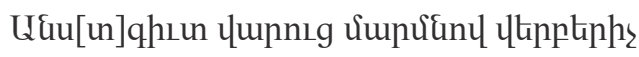
Ulnuntiul h hums pudulhis unphs

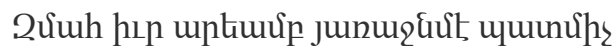

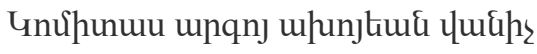

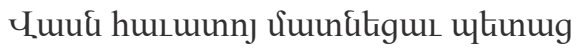

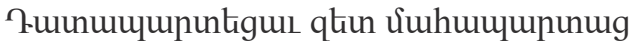

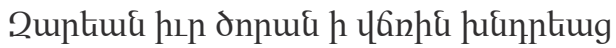
unứnumu unqnj purhs lnıumqqtiug

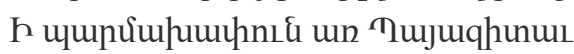

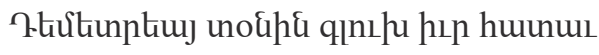

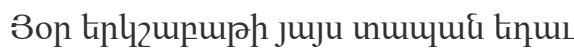

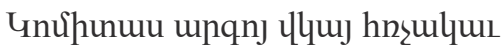
8nıgulp hnuzhg puqưuguid pnınul 2nnng lyuj 5 nıhunuinnumg onl

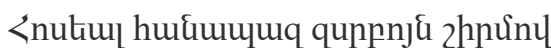

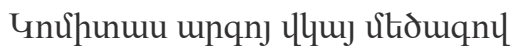

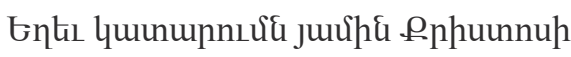

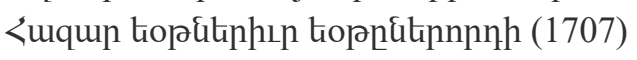

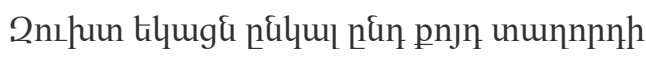

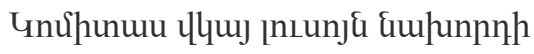

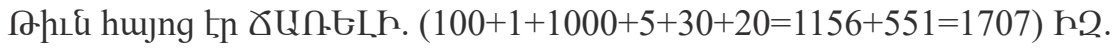
(26) hnluntiuptiph

74 See T'orosean, Vark' Mkbitaray abbayi Sebastioy, 231; and Vahram T'orgomean, "Tsanōt'agrut'iwně Stampoloy Patmut'ean Eremia Ch'èlēpi K'ēōmiwrchean," Handès Amsōreay 1-5 (1937): 203. 


\section{English Translation}

For the blessed martyr Rev. Komitas

Tomb of the dear clergyman

Of the priest of the great family K'eōmurchean

[With regards to his] city he is a native of prosperous Byzantium

Komitas with the venerable name Varsamean

Tall in stature, with a lively face

Superb in speech, wise in mind

He composed hymns with brilliant verses

Komitas venerable, erudite poet

He was showing an impeccable way of bodily life

Baptized for the cross, drinker of the chalice

He narrated his bloody death beforehand

Komitas the efficacious fighter [against Evil]

He was handed over to the Princes because of his faith

He was condemned like those who are sentenced to death

He asked that his blood be shed by [judicial] sentence.

Komitas the great atoner dressed in light

At the Parmak Gate near to the Bayezid [Mosque]

On the feast of Demetrios he was decapitated

On Monday he was placed in this tomb

Komitas the great martyr, with solemnity

Signs of miracles multiplied in number

Of which the testifier is the sea of pilgrims.

Flowing always around the tomb of the saint

Komitas the great martyr, highly praised

[The martyrdom] was completed in the year of Christ

The thousand seven-hundred and seventh (1707)

Receive your pilgrims with your odes

Oh Komitas witness of the light of [our] ancestors

In the year of the Armenians 1156 on 26 October. 


\section{Bibliography}

\section{Unpublished}

Galata Şer'iyye Sicilleri (GŞS) 202.

Mkhit'arean Monastery Library of Vienna, MS 1514.

\section{Published}

Albera, Dionigi, and Maria Couroucli (eds.): Sharing Sacred Spaces in the Mediterranean: Christians, Muslims, and Jews at Shrines and Sanctuaries, Bloomington: Indiana University Press, 2012.

Aslanian, Sebouh D.: Global Early Modernity and Mobility: Port Cities and Printers in the Armenian Diaspora, 1512-1800, forthcoming.

..... : "The 'Great Schism' of 1773: Venice and the Founding of the Armenian Community of Trieste," in Reflections on Armenian Identity in History and Historiography, ed. H. Berberian and J. Daryaee, Irvine: Jordan Center for Persian Studies, 2018.

..... : "Prepared in the Language of the Hagarites': Abbot Mkhitar's 1727 Armeno-Turkish Grammar of Modern Western Armenian," Journal of the Society for Armenian Studies, 25 (2016): 54-86.

..... : From the Indian Ocean to the Mediterranean: The Global Trade Networks of Armenian Merchants from New Julfa, Berkeley: University of California Press, 2011.

Avk'ereants', Step'anos: Allah'ın aziz kulu Kömürceants Der Gomidas kahanaynın varkı ve Nahadagutünü, Trieste: Self-Published with Persmission of Mikhit'arean publishing house, 1798.

Ayvazyan, Gayane: “Eremia Ch'lepi K'yomurchyani 'Ōragrut'yun' Erki Mi Anhayt Skzbnalbyuri Masin [Concerning an Unknown Primary Source for Eremia Ch'lepi K'eōmurchean's Diary]," Hayagitut'yan Harts'er, 1/7 (2016): 51-60.

Balta, Evangelia and Matthias Kappler (ed.): Cries and Whispers in Karamanlidika Books, Wiesbaden: Harrassowitz Verlag, 2010.

Bardakjian, Kevork: Modern Ermeni Edebiyatı, İstanbul: Aras, 2013.

Beydilli, Kemal: II. Mahmud Devrinde Katolik Ermeni Cemâati ve Kilisesinin Tanınması (1830), Harvard: Department of Near Eastern Languages and Civilizations, 1995.

Ch'amch'yants', Mik'ayel: Hayots' Patmut'iwn [History of Armenia], vol. III, Venice: Jiovanni Piats'oyi, 1786.

Cora, Yaşar Tolga: "Localizing Missionary Activities: Encounters Between Tondrakians, Protestants, and Apostolic Armenians in Khnus in the Mid-Nineteenth Century," The Ottoman East in the Nineteenth Century: Societies, Identities and Politics, ed. Yaşar Tolga Cora, Dzovinar Derderian and Ali Sipahi, London: I.B. Tauris, 2016.

Dictionnaire d'Histoire et de Géographie Ecclésiastique, Paris: Letouzey et Ané, 1912. 
Evliyâ Çelebi: Evliyâ Çelebi Seyahatnâmesi, vol. I-II, ed. Seyit Ali Kahraman, Yücel Dağlı, Robert Dankoff, İstanbul: Yapı Kredi Yayınları, 2011.

Frazee, Charles A.: Catholics and Sultans: The Church and the Ottoman Empire: 1453-1923, London: Cambridge University Press, 1983.

Grigor, Daranalts'i: Zhamanakagrut'iwn Grigor Vardapeti Kamakhets'wots' kam Daranalts'wots' [Chronicle of Vardapet Grigor Kamakhets'i or Daranalts'i], ed. Mesrop Nshanean, Jerusalem: Tparan Arak' At'orots' S. Yakobeants', 1915.

Hasluck, F.W.: Christianity and Islam under the Sultans, vol. I-II, Oxford: Oxford University Press, 1929).

Ivanova, Polina: "Armenians in Urban Order and Disorder of Seventeenth-Century Istanbul," Journal of the Ottoman and Turkish Studies Association, 4/2 (2017): 239-260.

K'eōmurchean, Eremia: Oragrutyun Eremia Ch'èlēpi K'ēomyurcheani [Eremia Ch'lepi K'ēmurchean's Diary], ed. Mesrop Nshanean, Jerusalem: Tparan Srbots'Yakobeants', 1939.

..... : Eremia Ch'èlēpi Kèōmyurchean Stampoloy Patmutyun [Eremia Ch'lepi K'eōmurchean’s History of Istanbul], ed. Vahram Y. T'orgomean, Vienna: Mkhit'arean Tparan, 1913.

Kévorkian, Raymond H.: "L'imprimerie Surb Ejmiacin et Surb Sargis Zōravar et le conflit entre Arméniens et catholiques à Constantinople (1695-1718)," Revue des études arméniennes, 15 (1981): 401-416

La Porta, Sergio: "Armeno-Latin Intellectual Exchange in the Fourteenth Century: Scholarly Traditions in Conversation and Competition," Medieval Encounters, 21 (2015): 269-294.

Lowry, Heath W.: In the Footsteps of the Ottomans: A Search for Sacred Spaces \& Architectural Monuments in Northern Greece, Istanbul: Bahçesehir University Publications, 2009.

Manandyan, Hakob and Hrach'ya Acharyȧn: Hayots' Nor Vkanerě: 1155-1843 [The NeoMartyrs of the Armenians], Ejmiatsin: Tparan Mayr At'oroy S. Ējmiatsin, 1903.

Nikodēmos o Agioreitēs: Neon Marturologion ètoi Marturia tōn Neofanōn Martu, Athens: F. Karampini and K. Vafa, 1856.

Nurikhan, Minas: The Life and Times of the Servant of God, Abbot Mechitar, Founder of the Mechitarist Fathers, Venice: St. Lazarus' Island Press, 1915.

Ohanjanyan, Anna: "Evangelical and Pentecostal Communities in Armenia: Negotiating Identity and Accommodation," Armenian Christianity Today: Identity Politics and Popular Practice, ed. Alexander Agadjanian, London: Ashgate, 2014.

Ōrmanean, Malak'ia: Azgapatum [National History], vol. II, Beruit: Sewan, 1960.

Pifer, Michael: "The Age of the Gharib: Strangers in the medieval Mediterranean," in An Armenian Mediterranean: Words and Worlds in Motion, ed. Kathryn Babayan and Michael Pifer, Cham: Palgrave Macmillan, 2018.

Riondel, H.: Une page tragique de l'histoire religieuse du Levant, Paris: Gabriel Beauchesne, 1929. 
Santus, Cesare: “Un Beato Martire Per La Nazione Martire. La Causa di Beatificazione del Sacerdote Armeno Gomidas Keaumurgian (1709-1929)," Un mestiere paziente: Gli allievi pisani per Daniele Menozzi, ed. Andrea Mariuzzo, et al., Pisa: Edizioni ETS, 2017.

..... : "The Şeyhülislam, the Patriarch, and the Ambassador: A Case of Entangled Confessionalization (1692-1703)," forthcoming in a volume edited by Tijana Kristic based on proceedings of conference entitled "Entangled Confessionalizations? Dialogic Perspectives on Community and Confession-Building Initiatives in the Ottoman Empire, 15th-18th Centuries" which took place at the Central European University in Budapest, Hungary in June 2018.

..... : Trasgressioni necessarie. Communicatio in sacris, coesistenza e conflitti tra le comunità cristiane orientali (Levante e Impero ottomano, XVII-XVIII secolo), Rome: École française de Rome, 2019.

..... : "Conflicting Views: Catholic Missionaries in Ottoman Cities between Accomodation and Latinization," Catholic Missionaries in Early Modern Asia: Patterns of Localization, ed. Nadine Amsler et al., London: Routledge, 2019.

Shapiro, Henry R.: "The Great Armenian Flight: Migration and Cultural Change in the Seventeenth-Century Ottoman Empire," Journal of Early Modern History, 23 (2019): 67-89.

Stepanyan, Hasmik: Catalogue of Turkish Materials Written in Armenian Letters of Armenian Manuscripts and Turkish Manuscripts in Armenian Letters: Manuscripts from "Matenadaran" in Yerevan and Mother See Holy St. Echmiadzin, Yerevan: National Academy of Sciences of Armenia Institute of Oriental Studies, 2008.

Thomas, David, and John A. Chesworth (ed.): Christian-Muslim Relations. A Bibliographical History, Leiden: Brill, 2017.

Thomson, Robert W. (trans.): Moses Khorenats $i$ : History of the Armenians, Cambridge: Harvard University Press, 1978.

Tietze, Andreas and Avedis K. Sanjian: Eremya Chelebi Kömürjian's Armeno-Turkish Poem: The Jewish Bride, Wiesbaden: Harrassowitz, 1981.

T'orgomean, Vahram: "Tsanōt'agrut'iwně Stampoloy Patmut'ean Eremia Ch'ēlēpi K'ēōmiwrchean [Note on Eremia Ch'lepi K'eōmurchean's History of Istanbul],' Handēs Amsōreay, 1-5 (1937): 192-209.

T'orosean, Hovhannēs: Vark' Mkhit'aray abbayi Sebastioy [Life of Abbot Mkhit'ar Sebastats'i], Venice: S. Lazar, 1901.

Vanlı Bir Ermeni ile Protestant Karoziç, Galata: St. Benedict Printing House, 1844.

Vartan Paşa: Akabi Hikayesi: İlk Türkçe Roman, 1851, ed. Andreas Tietze, İstanbul: Eren, 1991.

Vaporis, Nomikos Michael: Witnesses for Christ: Orthodox Christian Neomartyrs of the Ottoman Period, 1437-1860, Yonkers: St. Vladimir's Seminary Press, 2000. 